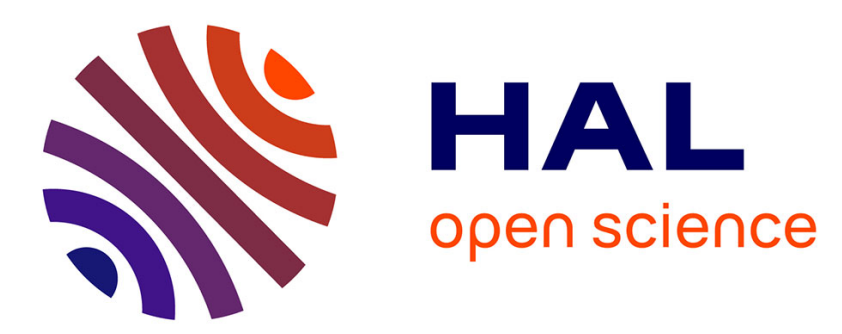

\title{
A hierarchical CoFe-layered double hydroxide modified carbon-felt cathode for heterogeneous electro-Fenton process.
}

Soliu O. Ganiyu, Thi Xuan Huong Le, Mikhael Bechelany, Giovanni Esposito, Eric D. van Hullebusch, Mehmet A. Oturan, M. Cretin

\section{To cite this version:}

Soliu O. Ganiyu, Thi Xuan Huong Le, Mikhael Bechelany, Giovanni Esposito, Eric D. van Hullebusch, et al.. A hierarchical CoFe-layered double hydroxide modified carbon-felt cathode for heterogeneous electro-Fenton process.. Journal of Materials Chemistry A, 2017, 5, pp.3655-3666. 10.1039/C6TA09100H . hal-01632937

\section{HAL Id: hal-01632937 https://hal.science/hal-01632937}

Submitted on 10 Jun 2021

HAL is a multi-disciplinary open access archive for the deposit and dissemination of scientific research documents, whether they are published or not. The documents may come from teaching and research institutions in France or abroad, or from public or private research centers.
L'archive ouverte pluridisciplinaire $\mathbf{H A L}$, est destinée au dépôt et à la diffusion de documents scientifiques de niveau recherche, publiés ou non, émanant des établissements d'enseignement et de recherche français ou étrangers, des laboratoires publics ou privés. 
Received 00th January 20xx Accepted 00th January 20xx DOI: $10.1039 / \times 0 \times x 00000 x$ www.rsc.org/

\title{
Hierarchical CoFe-Layered Double Hydroxide Modified Carbon-felt Cathode for Heterogeneous Electro-Fenton
}

Soliu O. Ganiyu ${ }^{a}$, Thi Xuan Huong Le ${ }^{b}$, Mikhael Bechelany, ${ }^{b},{ }^{*}$ Giovanni Espositoc, Eric D. van Hullebuscha, Mehmet A. Oturan ${ }^{\mathrm{a}}$, Marc Cretin ${ }^{\mathrm{b},{ }^{*}}$

\begin{abstract}
Hierarchical CoFe-Layered Double Hydroxide (CoFe-LDH) was grown on carbon felt (CF) as heterogeneous catalyst by insitu solvothermal growth. The CoFe-LDH/CF serves as cathode as well as $\mathrm{Fe}^{2+}$ (catalyst) source in electro-Fenton (EF) process. A combined structural and electrochemical characterization revealed highly ordered and well crystallized CoFe$\mathrm{LDH}$ anisotropically grown on CF substrate with highly dense urchin-like structures that were highly stable at circumneutral $\mathrm{pH}$. EF experiments with CoFe-LDH/CF cathode showed excellent mineralization of Acid Orange II (AO7) over a wide pH range $(2-7.1)$. The mineralization of $A O 7$ with CoFe-LDH/CF was by both homogeneous and surfaced catalyzed process at low acidic $\mathrm{pH}$, whereas only surface catalyzed process occurs at circumneutral $\mathrm{pH}$ due to stability of the LDH as well as precipitation of the catalyst. Higher mineralization was achieved with CoFe-LDH/CF compared to homogeneous EF with raw $\mathrm{CF}$ using $\mathrm{Fe}^{2+} / \mathrm{Co}^{2+}$ catalyst at all pH studied and the TOC removal with CoFe-LDH/CF cathode was at least 1.7 and 3.5 times higher than homogeneous system with $\mathrm{Fe}^{2+} / \mathrm{Co}^{2+}$ at $\mathrm{pH} 5.83$ and 7.1 respectively. The enhanced performance observed with CoFe-LDH/CF was ascribed to (i) surface-catalyzed reaction occurring at the surface of the cathode which can expand the working $\mathrm{pH}$ window and avoiding the precipitation of iron sludge as $\mathrm{pH}$ increases, (ii) enhanced generation of $\mathrm{H}_{2} \mathrm{O}_{2}$ due to improved electroactive surface area of the cathode and (iii) co-catalyst effect of the $\mathrm{Co}^{2+}$ in the $\mathrm{LDH}$ that can promote regeneration and additional production of $\mathrm{Fe}^{2+}$ and hydroxyl radical, respectively. The CoFe-LDH/CF cathode exhibited relatively good reusability as the TOC removal after $2 \mathrm{~h}$ was still above $60 \%$ after 7 cycles of degradation, indicating that the prepared CoFe-LDH/CF is a promising cathode for the removal of organic pollutants by EF technology.
\end{abstract}

\section{Introduction}

Electro-Fenton process (EF) is an eco-friendly electrochemical advanced oxidation process (EAOP) based on classical Fenton's reaction chemistry in which organic contaminants are destroyed by in-situ homogenously generated hydroxyl radical $(\cdot \mathrm{OH})$ from the Fenton's reaction (eq. 1) between $\mathrm{Fe}^{2+}$ ion and hydrogen peroxide $\left(\mathrm{H}_{2} \mathrm{O}_{2}\right)[1-4]$.

$\mathrm{Fe}^{2+}+\mathrm{H}_{2} \mathrm{O}_{2}+\mathrm{H}^{+} \rightarrow \mathrm{Fe}^{3+}+\cdot \mathrm{OH}+\mathrm{H}_{2} \mathrm{O}$

(eq. 1)

The in-situ production of $\mathrm{H}_{2} \mathrm{O}_{2}$ by $2 \mathrm{e}^{-}$reduction of dissolved oxygen (eq. 2) at the cathode has great influence on the efficiency of the EF process and the production rate depends on the nature of cathode materials [5-7].

$\mathrm{O}_{2}+2 \mathrm{H}^{+}+2 \mathrm{e}^{-} \rightarrow \mathrm{H}_{2} \mathrm{O}_{2}$

(eq.

2)

An interesting characteristic of EF process is that only catalytic quantity of $\mathrm{Fe}^{2+}$ is required because it can be regenerated at the cathode by $\mathrm{e}^{-}$reduction of $\mathrm{Fe}^{3+}$ (eq. 3) formed from Fenton's

a. Université Paris-Est, Laboratoire Géomatériaux et Environnement (LGE), EA 4508, UPEM, 77454 Marne-la-Vallée, France

b. IEM (Institut Européen des Membranes), UMR 5635 (CNRS-ENSCM-UM), Université de Montpellier, Place E. Bataillon, F-34095 Montpellier, Cedex 5, France

c. Department of Civil and Mechanical Engineering, University of Cassino and Southern Lazio, Via Di Biasio 43, 03043 Cassino (FR), Italy.

*Corresponding author.E-mail: mikhael.bechelany@univ-montp2.fr

*Corresponding author. E-mail: Marc.Cretin@univ-montp2.fr reaction (eq. 1) [1,8-10].

$\mathrm{Fe}^{3+}+\mathrm{e}^{-} \rightarrow \mathrm{Fe}^{2+}$

(eq. 3)

The in situ electrogeneration of $\mathrm{H}_{2} \mathrm{O}_{2}$ (eq. 2) and the electroregeneration of $\mathrm{Fe}^{2+}$ from $\mathrm{Fe}^{3+}$ produced in Fenton's reaction (eq. 3) allow continuous formation of $\bullet \mathrm{OH}$ that is able to destroy any organic pollutant $[1,11]$.

The major challenges of homogeneous $\mathrm{EF}$ with $\mathrm{Fe}^{2+}$ are the narrow working $\mathrm{pH}$ window and non-reusability of the catalyst in several runs [12-14]. Optimization of the quantity of $\mathrm{Fe}^{2+}$ is another problem because excessive quantities of $\mathrm{Fe}^{2+}$ in the solution may promote the wasting reaction (eq. 4) that consumes the generated $\bullet \mathbf{O H}$, thus reduce the efficiency of the process $[15,16]$.

$\mathrm{Fe}^{2+}+\cdot \mathrm{OH} \rightarrow \mathrm{Fe}^{3+}+\mathrm{OH}^{-}$

(eq.

4)

To avoid these problems, heterogeneous EF with Fe containing solid catalyst or modified electrodes has been developed for the effective oxidation of organic pollutants over a wide range of $\mathrm{pH}$ with excellent stability and reusability of the catalyst. Heterogeneous catalyst such as pyrite $[17,18]$, magnetite [19] goethite [20], Fe/Mn-loaded alginate [21] and Fe-carbon PTFE [22] have been studied in EF treatment of organic pollutants. Fe@Fe-oxides functionalized cathodic materials such as pyrrhotite grafted on graphite by conductive silver paste [23], $\mathrm{Fe} @ \mathrm{Fe}_{2} \mathrm{O}_{3}$ nanowires mixed with carbon nanotubes and fixed on tetrafluoroethylene (PTFE) [12], activated carbon-supported nano-geothite $(\mathrm{FeOOH})$ [20], Fe-modified activated carbon $[24,25]$ and Fe-impregnated carbon-felt [26] electrodes have 
been investigated as catalyst source as well as cathode for EF oxidation at a wider $\mathrm{pH}$ range. Recently, Ferrite-carbon [14], FeCuC [27] and $\mathrm{Fe}_{3} \mathrm{O}_{4}-\mathrm{C}[28,29]$ aerogel have be synthesized in either one pot or more complex method and studied as efficient cathode materials to enhanced electro-Fenton reactivity at acidic and neutral pHs.

The development of new electrodes that incorporates electrochemically active second phase containing transition metal oxides/hydroxides coated on carbon based matrixes for pseudo-capacitors used in energy conversion/storage devices $[30,31]$ and electrochemical water oxidation $[32,33]$ may be of great application in Fenton based EAOPs. The transition metals in the carbon based matrix electrode can act as heterogeneous catalyst which reacts with in-situ generated $\mathrm{H}_{2} \mathrm{O}_{2}$ in a Fenton or Fenton-like reaction. Layered double hydroxides (LDHs) are anionic clay materials that contain a brucite sheets of metallic cations ( $\mathrm{M}^{\prime \prime}$ and $\mathrm{M}^{\prime \prime \prime}$ ) octahedrally coordinated by hydroxyl groups, forming $\mathrm{M}^{\prime \prime}(\mathrm{OH})_{6} / \mathrm{M}^{\prime \prime \prime}(\mathrm{OH})_{6}$ octahedral with chargecompensating anions positioned within the interlayer space $[34,35]$. Transition metal based LDHs possess tunable compositions and high dispersion of cations in their octahedral sheets which sometimes gives them astonishing electrochemical properties and have found several applications such as biosensors, alkaline secondary batteries, supercapacitors and recently used as electrocatalyst in water splitting/oxidation reaction [36,37]. These properties can also be harness for electrochemical wastewater treatment, with the transition metals catalyzed the process in a heterogeneous EF process. The possibility of using other transition metals such as copper, cobalt, and manganese [38-40] that have been tested as co-Fenton catalyst with Fe to improve the efficiency of EF process will be an added advantage of using LDH incorporated carbon based matrix cathode.

Additionally, the modification of carbon based matrix electrodes with LDH may also enhanced the generation of $\mathrm{H}_{2} \mathrm{O}_{2}$ due to increased electroactive surface area [41]. In fact, Le et al.[42] have shown that graphene modified carbon-felt cathode achieved better mineralization of azo-dye Acid Orang II (AO7) compared to raw carbon-felt due to the increase in electroactive surface area, which in turn enhance in-situ generation of $\mathrm{H}_{2} \mathrm{O}_{2}$. Therefore, this present study investigates for the first time, the use of hierarchical CoFe-LDH grown on carbon-felt cathode for efficient degradation and mineralization of a model organic pollutant. The modified cathode was prepared by in-situ solvothermal process. The structural and electrochemical properties of the prepared cathode were examined by XRD, SEM-EDX, FTIR, XPS and cyclic voltammetry and electrochemical impedance spectroscopy. AO7, a common azo-dye found in high concentration in wastewater and effluent discharge from textile industries $[43,44]$ was used as model pollutant. Besides, the influence of hydrothermal treatment parameters such as temperature, initial concentration of growth solution and treatment time on the performance of the prepared cathode was extensively studied. More importantly, the mineralization of $\mathrm{AO} 7$ solution by heterogeneous EF over a wide $\mathrm{pH}$ range as well as the leaching of the $\mathrm{Co} / \mathrm{Fe}$ in the treated solution was systematically examined. For comparison, analogous studies were made with raw CF using externally added $0.2 \mathrm{mM} \mathrm{Fe}^{2+}, \mathrm{Co}^{2+}$ or $\mathrm{Co}^{2+} / \mathrm{Fe}^{2+}(1: 1$ and $2: 1)$ as this value was reported in literature as the optimum concentration of $\mathrm{Fe}^{2+}$ for EF process [45].

\section{Experimental}

\section{Reagents and Materials}

Carbon felt was obtained from Alfa Aesar. Cobalt II nitrate tetrahydrate, $\mathrm{Co}\left(\mathrm{NO}_{3}\right)_{2} .4 \mathrm{H}_{2} \mathrm{O}$ (> 99\% purity); iron III nitrate nonahydrate, $\mathrm{Fe}\left(\mathrm{NO}_{3}\right)_{3} .9 \mathrm{H}_{2} \mathrm{O}(98 \%$ purity); iron II sulfate heptahydrate, $\mathrm{FeSO}_{4} .7 \mathrm{H}_{2} \mathrm{O}$ (> 99\% purity); urea, $\mathrm{CO}\left(\mathrm{NH}_{2}\right)_{2}$ and ammonium fluoride, $\mathrm{NH}_{4} \mathrm{~F}$ (99\% purity) were purchased from Sigma Aldrich and used in the synthesis of $\mathrm{LDH}$ coated on the carbon-felt without further purification. AO7, $\mathrm{C}_{16} \mathrm{H}_{11} \mathrm{~N}_{2} \mathrm{NaO}_{4} \mathrm{~S}$ (Orange II sodium salt) and sodium sulfate, $\mathrm{NaSO}_{4}$ (anhydrous, $99-100 \%)$ were also supplied by Sigma Aldrich. All solutions were prepared with ultra-pure water obtained from a Millipore Mill-Q system with resistivity $>18 \mathrm{M} \Omega \mathrm{cm}$ at room temperature.

\section{Electrode preparation}

The CoFe-LDH modified carbon felt (CoFe-LDH/CF) cathode was prepared by in-situ solvothermal process $[46,47]$ in which CoFe$\mathrm{LDH}$ was grown on $\mathrm{CF}$ substrate. The growth solution contains $\mathrm{Co}\left(\mathrm{NO}_{3}\right)_{2} .6 \mathrm{H}_{2} \mathrm{O}, \mathrm{Fe}\left(\mathrm{NO}_{3}\right)_{3} .9 \mathrm{H}_{2} \mathrm{O}, \mathrm{NH}_{4} \mathrm{~F}(0.125 \mathrm{M})$ and $\mathrm{CO}\left(\mathrm{NH}_{2}\right)_{2}$ $(0.5 \mathrm{M})$ dissolved in $100 \mathrm{~mL}$ of Milli-Q water with molar ratio of $\mathrm{Co} / \mathrm{Fe}=2: 1(n / n)$. The homogeneous solution was vigorously stirred for $30 \mathrm{~min}$ before transferred into a Teflon-lined stainless steel autoclave. Raw CF substrate $(6.0 \mathrm{~cm}$ length $\times 1.0$ $\mathrm{cm}$ width $\times 1.27 \mathrm{~cm}$ thickness) was pretreated with concentrated $\mathrm{HNO}_{3}$ and then washed in turn in ultrasonic bath with deionized water, acetone, ethanol and deionized water for 15 min each. The clean CF was immersed into the growth solution in Teflon autoclave for hydrothermal treatment at predetermined temperature and period. Subsequently, both the substrate coated with $\mathrm{LDH}$ and the solid LDH suspension were separated from the solution, washed extensively with distilled water followed by Milli-Q water and oven dried at 40 ${ }^{\circ} \mathrm{C}$. The sample used for studying leaching of catalyst and reusability were dried at $80^{\circ} \mathrm{C}$

\section{Characterization}

The surface morphology of the as-prepared cathode was analyzed by SEM (Hitachi S-4800), with an accelerating voltage of $10 \mathrm{kV}$, combined with EDX. TEM images were taken with a PHILLIP-CM 20. XRD were recorded on a BRUKER $\$ 5000$ diffractometer, using $\mathrm{Cu}-\mathrm{K} \alpha$ radiation $(0.15418 \mathrm{~nm})$ at $40 \mathrm{kV}$ and $20 \mathrm{~mA}$. FTIR pattern of the powder LDH was performed on NEXUS FTIR (ThermoFisher). The surface chemistry of the prepared sample was analyzed by XPS (ESCALAB 250 Thermal Electron) with AlK $\alpha$ (1486.6 eV). Cyclic voltammetry (CV) experiments were carried out in solution of $50 \mathrm{mM} \mathrm{Na} \mathrm{SO}_{4}$ using M3AUT70466 Autolab System (Eco Chemie BV, Netherlands) without external addition $\mathrm{Fe}^{2+}$ source. A Threeelectrodes cell consisting of $\mathrm{CoFe}-\mathrm{LDH} / \mathrm{CF}$ as a working 
electrode, Pt foil and Saturated Calomel Electrode (SCE) as a counter and reference electrodes respectively was used to conduct the CV experiments. The electrical conductivity of the prepared cathode was determined by measuring electrode interfacial-charge transfer resistance using electrochemical impedance spectroscope (EIS). The EIS was performed at an open circuit voltage with voltage amplitude of $10 \mathrm{mV}$ in a frequency range of $50 \mathrm{kHz}$ to $100 \mathrm{MHz}$.

\section{EF experiment}

The EF experiments were performed in an open, undivided cylindrical glass cell of diameter $4 \mathrm{~cm}$ and $300 \mathrm{~mL}$ capacity equipped with platinum $(\mathrm{Pt})$ gauze anode, placed in parallel to the cathode $(4.5 \mathrm{~cm} \times 1 \mathrm{~cm} \times 1.27 \mathrm{~cm})$ made of CoFe-LDH/CF at a distance of $2 \mathrm{~cm}$. All experiments with CoFe-LDH/CF cathode were performed with $150 \mathrm{~mL} \mathrm{AO7}$ solutions (0.1 mM) containing $0.05 \mathrm{M} \mathrm{Na}_{2} \mathrm{SO}_{4}$ as supporting electrolyte. The solution was constantly stirred by PTFE magnetic bar to ensure mass transfer towards the electrodes. Compressed air was continuously bubbled into the solution at about $1 \mathrm{~L} \mathrm{~min}{ }^{-1}$, starting at $10 \mathrm{~min}$ prior to electrolysis to maintain a stationary $\mathrm{O}_{2}$ level.

\section{Instrument and analytic procedure}

All electrolyses experiments were performed with Lambda single power supply (Lambda Electronique, USA) at constant applied current of $-40 \mathrm{~mA}$. AO7 solution $\mathrm{pH}$ was adjusted with 1 $\mathrm{M} \mathrm{H}_{2} \mathrm{SO}_{4}$ or $\mathrm{NaOH}$ and was measured with a $\mathrm{pH} 209 \mathrm{pH}$-meter from HANNA Instruments (Romania). The mineralization of the AO7 solutions was assessed from the decay of dissolved organic carbon, which can be considered as the total organic carbon (TOC) for highly water soluble organic compounds. The TOC of initial and electrolyzed samples were measured on a Shimadzu TOC-L CSH/CSN analyzer. Reproducible TOC values with $\pm 2 \%$ accuracy were obtained using the non-purgeable organic carbon method. Calibration curves for total organic (TC) and inorganic carbon (IC) analysis were built up by automatic dilution of standards solutions containing potassium hydrogen phthalate and sodium hydrogen carbonate for TOC and IC, respectively. Percentage of TOC removal was calculated from to the following equation:

TOC removal $(\%)=\frac{\Delta(\mathrm{TOC}) \exp }{\mathrm{TOC}_{0}} \times 100$

where $\Delta$ (TOC) $)_{\exp }$ is the experimental TOC decay at electrolysis time $\mathrm{t}\left(\mathrm{mg} \mathrm{L}^{-1}\right)$ and $\mathrm{TOC}_{\mathrm{o}}$ is the corresponding initial value prior to electrolysis.

The leaching of both Co and Fe from as-prepared CoFe-LDH/CF cathode into the treated solution was monitored by Optima 8300 Optical Emission Spectrometer with Inductively Coupled Plasma (ICP-OES) (Perkin Elmer) at absorption wavelength of 230 and $239 \mathrm{~nm}$ for Co and Fe respectively. Standard solutions of different concentrations were prepared with Perkin Elmer IV (1000 ppm) by dilution with acidified Milli-Q water. The organic intermediate formed after $20 \mathrm{~min}$ of electrolysis were identified by GC-MS.

\section{Results and discussion}

\section{Preparation of CoFe-LDH/CF electrode}

CF, a well-known carbonaceous cathode for Fenton based EAOPs was used as a substrate for in-situ growth of CoFe-LDH multiwall, which serves as heterogeneous catalyst/co-catalyst for EF process. The reactions at hydrothermal temperature mainly involve progressive hydrolysis of $\mathrm{NH}_{4} \mathrm{~F}$ and decomposition of $\mathrm{CO}\left(\mathrm{NH}_{2}\right)_{2}$ to $\mathrm{NH}_{4} \mathrm{OH}$ (eq. 6 and 7). The resulting alkaline solution induces homogeneous nucleation, crystallization and growth of metallic hydroxides on the substrate (eq. 8 ) $[47,48]$ :

$\mathrm{NH}_{4} \mathrm{~F}+\mathrm{H}_{2} \mathrm{O} \rightarrow \mathrm{NH}_{4}^{+}+\mathrm{OH}^{-}+\mathrm{HF}$

$\mathrm{CO}\left(\mathrm{NH}_{2}\right)_{2}+3 \mathrm{H}_{2} \mathrm{O}+$ heat $\rightarrow 2 \mathrm{NH}^{+}+2 \mathrm{OH}^{-}+\mathrm{CO}_{2}$ (eq. 6)

C $\left.\mathrm{CH}_{2}\right)_{2}+3 \mathrm{CO}_{2}$ (eq.

$\mathrm{Co}^{2+}+\mathrm{Fe}^{3+}+\mathrm{OH}^{-} \rightarrow \mathrm{CoFe}-\mathrm{LDH}$

The CF immersed in the growth solution acts as high energy sites for the nucleation and growth of the LDH on its surface compared to other sites in the growth solution.

\section{Structural and morphological properties of the CoFe-LDH/CF} SEM image of pretreated CF shows that it is clean, without organic and inorganic impurities that may have inherited during production process (Figure 1a). After solvothermal synthesis, there was anisotropic growth of hierarchical CoFe-LDH on the $\mathrm{CF}$ as shown in Figure 1b-h, with the density/quantity of coating on the CF substrate closely related to the hydrothermal treatment temperature, time and initial concentration of the growth solution. In fact, treatment at $70{ }^{\circ} \mathrm{C}$ and 25:12.5 (n/n) initial $\mathrm{Co}^{2+} / \mathrm{Fe}^{3+}$ concentration yielded a growth of fine but low dense LDH wall on the CF (Figure 1b), indicating only nucleation of the LDH particles with limited crystal growth. The quantity of CoFe-LDH deposited on the CF at this temperature was not sufficient enough as it showed little enhancement of mineralization of organic pollutant (as demonstrated in section 3.4.2). Synthesis made at higher temperature of $90{ }^{\circ} \mathrm{C}$ with similar concentration for period of $4 \mathrm{~h}$ produced a highly dense and extensive growth of $\mathrm{LDH}$ on the CF substrate with formation of few urchin-like structures (Figure 1c). These urchin-like structures extensively grown and increased in quantity for synthesis at $90{ }^{\circ} \mathrm{C}$ but longer period of time $(7 \mathrm{~h})$ (Figure 1d). For these synthesis conditions, it can be observed that the CF strands were entirely coated with CoFe-LDH, which are adhesively grafted on the CF. The magnified image (Figure 1e) revealed that the CoFe-LDH wall and urchin-likes structures are distributed across the entire surface of each CF strand, interconnected with each other, highly rough and porous which can enhance the diffusion of substance within the electrode. Further increase in hydrothermal treatment period to $21 \mathrm{~h}$ (Figure 1f) as well as temperature $\left(120^{\circ} \mathrm{C}\right)$ (Figure $1 \mathrm{~g}$ ) at this concentration shows little or no change in the morphology of the CoFe-LDH coated on CF substrate. Additionally, as shown in Figure $1 \mathrm{~h}$, the increase in the initial concentration of the growth solution (i.e. 50:25) does not enhance the quantity of CoFe-LDH deposited on the CF substrate. The surface compositions of the LDH coated CF were analyzed by EDX and the elemental peaks of $\mathrm{C}, \mathrm{O}, \mathrm{Fe}$ and $\mathrm{Co}$ were obtained. Interestingly, the molar ratio of Co to Fe was found to be 2.17, consistent with the initial and 
normal molar ratio of $\mathrm{M}^{\prime \prime} / \mathrm{M}^{\prime \prime \prime}$ in $\mathrm{LDH}$. Besides, elemental peak of $F$ was detected, which may be one of the interlayer anions that neutralized the excess positive charge of LDH layers. The $O$ peak emanates mainly from octahedral $-\mathrm{OH}$ and interlayer water.

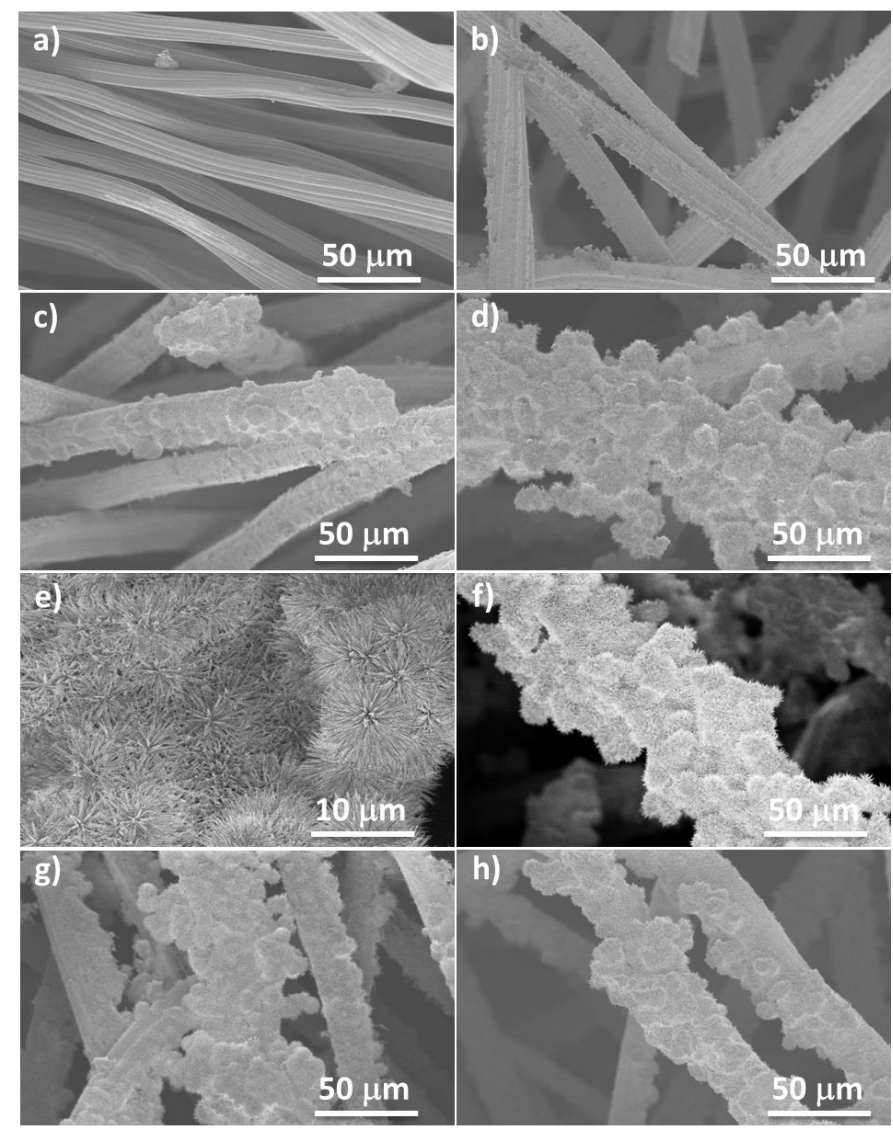

Figure 1. SEM images of (a) raw CF, (b) CoFe-LDH/CF $-70^{\circ} \mathrm{C}$ for $7 \mathrm{~h}$ (c) CoFe-LDH/CF -90 ${ }^{\circ} \mathrm{C}$ for $4 \mathrm{~h}$ (d) CoFe-LDH/CF $-90{ }^{\circ} \mathrm{C}$ for $7 \mathrm{~h}$ (e) magnified image of (d), (f) CoFe-LDH/CF $90{ }^{\circ} \mathrm{C}$ for $21 \mathrm{~h}$ (g) CoFe-LDH/CF $-120^{\circ} \mathrm{C}$ for $7 \mathrm{~h}$ and (h) CoFe-LDH/CF $-90^{\circ} \mathrm{C}$ for $7 \mathrm{~h}$. Note: (a-f) $-25: 12.5$ and $(\mathrm{h})-50: 25\left(\mathrm{Co}^{2+} / \mathrm{Fe}^{3+}\right)$

The TEM images (Figure 2) of CoFe-LDH deposited on CF showed rod-like structures with average width of 30-40 nm and lengths up to $400 \mathrm{~nm}$. The CoFe-LDH plates were intercalated with each other to form a hierarchical network, which provide both high specific surface area and fast diffusion of substance within the structure for excellent electrochemical reactions.

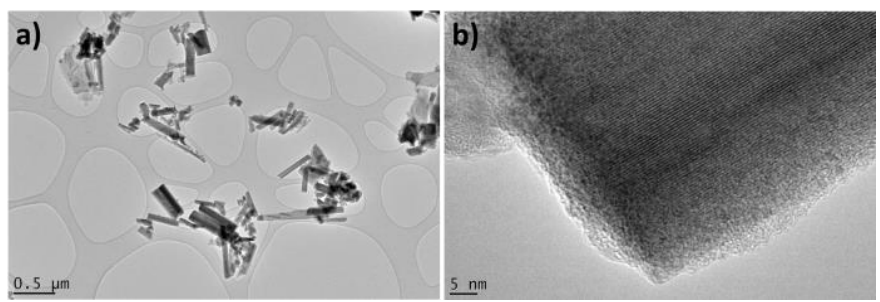

Figure 2. TEM images of CoFe-LDH.

The XRD patterns of the CoFe-LDH powder (Figure 3a, upper diffractogram) and CoFe-LDH/CF cathode (Figure 3a, lower diffractogram) showed characteristic reflections corresponding to the crystal planes (003), (006), (009), (012), (015), and (018), of a typical layered hydrotalcite-like phase. A good symmetry was obtained in the as-prepared LDH and LDH/CF as shown by the weak peaks at $2 \theta=54.9^{\circ}$ and $57^{\circ}$, assigned to (110) and (113) crystal planes[49,50]. The broad peak at $2 \theta=23.4^{\circ}$ and $43.7^{\circ}$ in lower diffractogram of Figure $3 a$ was characteristic of carbon substrate on which the LDH was grown. It is important to note that no other crystalline phase was detected, indicating the high purity of the LDH phase grown on the CF substrate. The functional groups present in the as-prepared LDH/CF were examined from ATR FT-IR spectrum (Figure $3 \mathrm{~b}$ ) of the powder CoFe-LDH using diamond indenter. The FT-IR spectrum was recorded in the wavelength range of $400-4000 \mathrm{~cm}^{-1}$. As could be seen from the FTIR spectrum, a narrow band observed at around $3690 \mathrm{~cm}^{-1}$ was associated to the stretching vibration of non-hydrogen bonded $\mathrm{O}-\mathrm{H}$ groups (OH in the brucite sheet). The second band located at $3470 \mathrm{~cm}^{-1}$ could be ascribed to the stretching vibration mode of hydrogen bonded $\mathrm{O}-\mathrm{H}$ groups (interlayer water) in the CoFe-LDH $[50,51]$. The bands between $2400-1900 \mathrm{~cm}^{-1}$ were due to diamond indenter of the FT-IR. A small absorption band located at $1610 \mathrm{~cm}^{-1}$ was assigned to the bending vibration of absorbed water molecules onto the CoFe$\mathrm{LDH}$ via hydrogen bonding. The strong absorption band at 1420 $\mathrm{cm}^{-1}$ is characteristic of $\mathrm{N}-\mathrm{O}$ stretching mode of the surface adsorbed and interlayer nitrate species, which is predominantly from the starting reactants in growth solution (i.e. $\mathrm{Co}\left(\mathrm{NO}_{3}\right)_{2} \cdot 6 \mathrm{H}_{2} \mathrm{O}$ and $\left.\mathrm{Fe}\left(\mathrm{NO}_{3}\right)_{3} \cdot 9 \mathrm{H}_{2} \mathrm{O}\right)$. Additionally, $\mathrm{CO}_{3}{ }^{2-}$ may also be identified as adsorbed or interlayer anions as shown by small band at $1050 \mathrm{~cm}^{-1}$, which may come from adsorption of $\mathrm{CO}_{2}$ either from the atmosphere or during the synthesis from the decomposition of urea [49]. Other bands observed in the lower wavelength region ( 856 and $735 \mathrm{~cm}^{-1}$ ) can be associated with stretching vibration of $\mathrm{M}-\mathrm{OH}$ and $\mathrm{M}-\mathrm{O}$ bondings $(\mathrm{M}=\mathrm{Co}$ and $\mathrm{Fe}$ ) in the brucite sheet of the LDH [52].
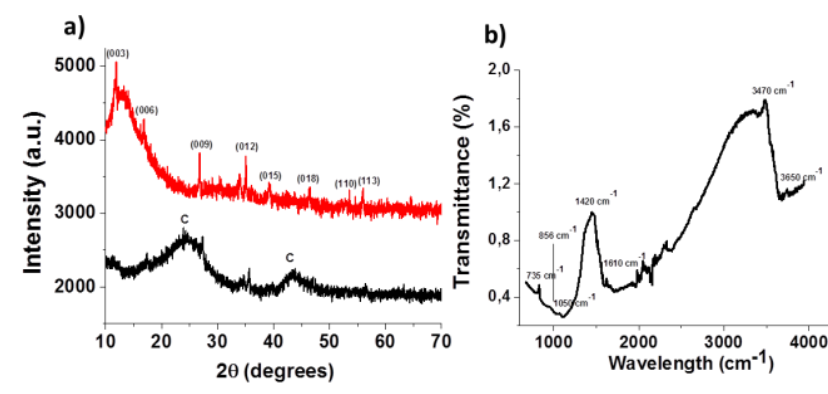


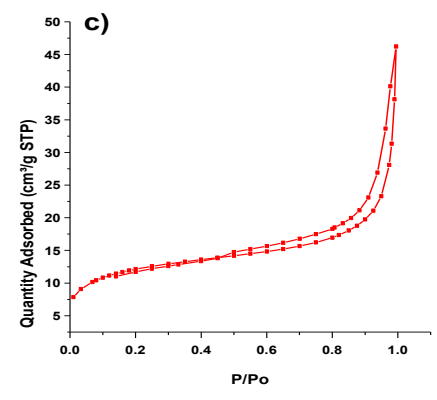

Figure 3. (a) XRD pattern of the powder CoFe-LDH (red curve) and CoFe-LDH/CF electrode (black curve), (b) FTIR - spectrum of the powder CoFe-LDH and (c) $\mathrm{N}_{2}$ adsorption isotherm of CoFe-LDH.

The $\mathrm{N}_{2}$ adsorption-desorption result for CoFe-LDH showed type IV isotherm with hysteresis loop typical of mesoporous material. The BET surface area was $42.9 \mathrm{~m}^{2} \mathrm{~g}^{-1}$ and the total pore volume $0.18 \mathrm{~cm}^{3} \mathrm{~g}^{-1}$.

The chemical composition and electronic states at the surface of the as-prepared CoFe-LDH on CF were analyzed by XPS, as shown in Figure $4 a$ and $b$, the Co $2 p$ core lines split into Co $2 p_{3 / 2}$ (782.5 eV) and Co $2 \mathrm{p}_{1 / 2}(798.2 \mathrm{eV})$ peaks with the later accompanied by a satellite band at $803.4 \mathrm{eV}$ (Figure 4a), demonstrative of a high-spin Coll state in the LDH material $[50,53]$. Similarly, the peaks of Fe $2 p_{3 / 2}$ and Fe $2 p_{1 / 2}$ emanates from the splitting of Fe $2 p$ lines are located at 711.3 and 724.8 $\mathrm{eV}$ (Figure 4b) respectively, having a spin energy separation of $13.5 \mathrm{eV}$ [54]. The XPS spectra showed C1s core line at $287.5 \mathrm{eV}$, confirming the existence of carbon (Figure 4c). Existential state of other elements such as $\mathrm{N}, \mathrm{O}$ and $\mathrm{F}$ in the CoFe-LDH/CF were confirmed by XPS as shown in Figure 4d.
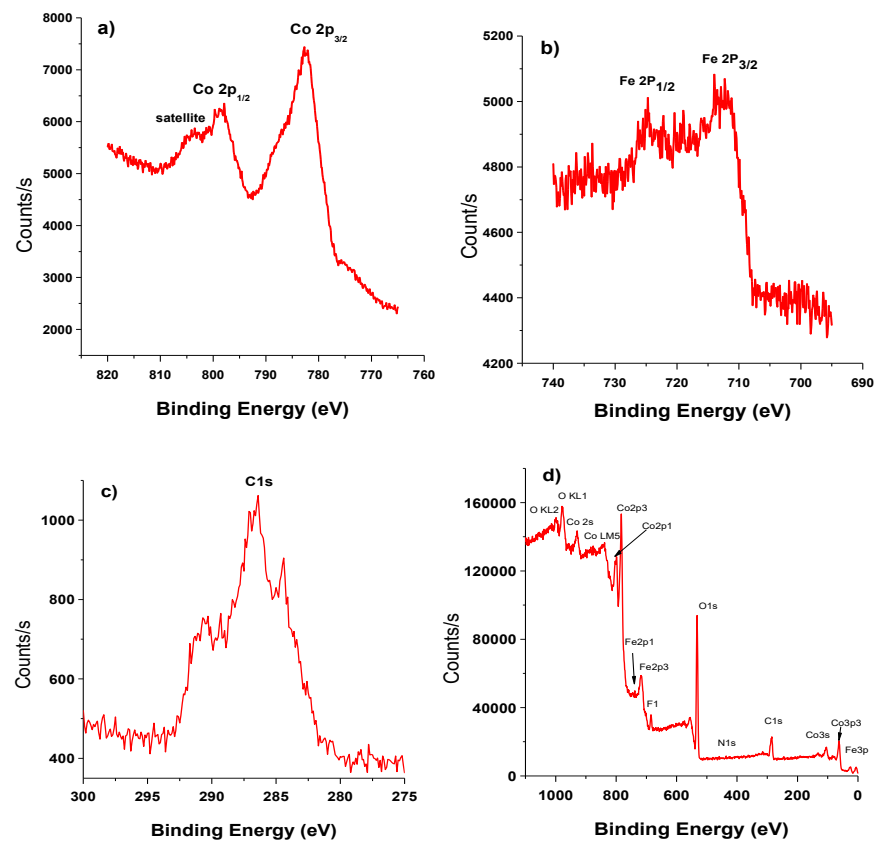

Figure 4. XPS spectra for (a) Co 2p, (b) Fe 2p, (c) C1s and (d) existential state of $\mathrm{Co}, \mathrm{Fe}, \mathrm{C}$, $\mathrm{O}$ and $\mathrm{N}$ of $\mathrm{COFe}-\mathrm{LDH} / \mathrm{CF}$

\section{Electrochemical behavior of the CoFe-LDH/CF}

Cyclic voltammetry of the CoFe-LDH/CF $\left(25: 12.5,90{ }^{\circ} \mathrm{C}\right.$ and $7 \mathrm{~h}$ treatment) in $50 \mathrm{mM} \mathrm{Na}_{2} \mathrm{SO}_{4}$ aqueous electrolyte at different pHs were shown in Figure 5a. This study was essential in order to determine the contribution of the homogeneous Fenton's oxidation to the overall mineralization of the pollutants and the stability of the prepared cathode with $\mathrm{pH}$. Two pairs of redox peaks at $\sim 0.25 \mathrm{~V} v s$. SCE and $\sim 0.56 \mathrm{~V} v$ s. SCE during the anodic and cathodic sweeps were clearly observed at $\mathrm{pH} 2$ and 3 , indicating iron reduction and oxidation respectively $\left(\mathrm{Fe}^{3+} / \mathrm{Fe}^{2+}\right.$ redox couple). This implies that $\mathrm{Fe}^{\text {III }}$ was leached into the solution. The peak current increased with the decrease of $\mathrm{pH}$, revealing the gradual leaching of $\mathrm{Fe}$ and $\mathrm{Co}$ into the solution since LDH became less stable as the solution becomes more acidic. The presence of $\mathrm{Co}$ in the solution could lead to extra reversible conversion redox processes via reduction of $\mathrm{Fe}^{3+}$ by $\mathrm{Co}^{2+}$ [52]. No redox peak was observed at $\mathrm{pH} 5.83$, indicating high stability of the CoFe-LDH coat on CF with negligible leaching of the metal ions into the solution
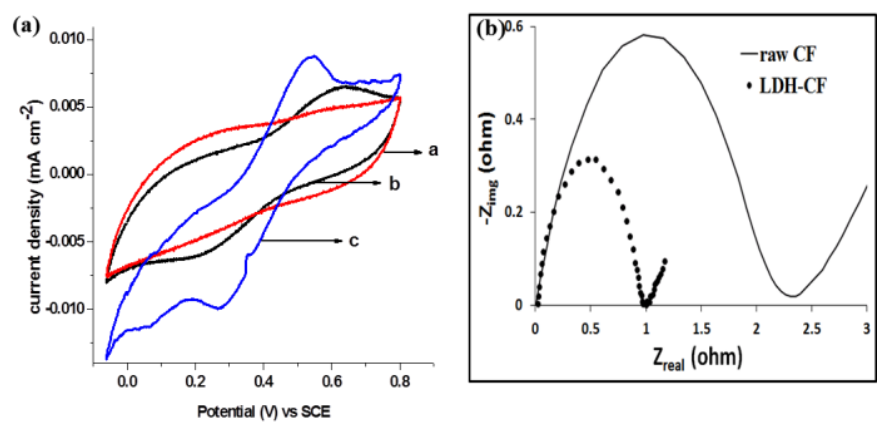

Figure 5. (a) CVs of CoFe- $\mathrm{LDH} / \mathrm{CF}$ (synthesized at $90^{\circ} \mathrm{C}$ for $7 \mathrm{~h}$ ), in $50 \mathrm{mM} \mathrm{Na}_{2} \mathrm{SO}_{4}$ at scan rate $50 \mathrm{mVs}^{-1}$ : Curves at (a) pH 5.83, (b) pH 3 and (c) pH 2; and (b) EIS spectra of raw and CoFe-LDH modified CF.

Generally in EF process, excellent electrochemical properties (i.e. conductivity) of the electrode are as essential as the Fenton catalytic activity. The interface properties and potential of electron transfer between the electroactive substance and the prepared electrode was investigated by EIS. Figure $5 \mathrm{~b}$ shows the electrochemical impedance spectra of raw and CoFe-LDH modified CF electrodes. The Nyquist plots presents suppressing semicircle arcs corresponding to the interfacial charge-transfer resistance $\left(R_{c t}\right)$ with the intercepts on the real axis provides the actual value of $R_{c t}$ (i.e. the diameter of the semicircle). As can been seen in Figure 5b, There was increase of interfacial resistance and in turn, decrease of electrical conductivity of the CF cathode after the modification with CoFe-LDH as shown by increase of the intercept of the Nyquist plot. However, the $R_{c t}$ obtained was 0.97 and $2.3 \Omega$ for raw CF and CoFe-LDH/CF respectively, indicating that the $\mathrm{CF}$ still maintains excellent conductivity after been modified with CoFe-LDH. The increase in $\mathrm{R}_{\mathrm{ct}}$ of CF from 0.97 to $2.3 \Omega$ after modification with CoFe-LDH was expected since the LDH coating is non-conducting solid.

4. Mineralization of $\mathrm{AO7}$ by EF process using CoFe-LDH/CF cathode over wide $\mathrm{pH}$ range 
The performance of the as-prepared CoFe-LDH/CF as a suitable cathode as well as catalyst source for heterogeneous EF process was evaluated by studying the mineralization of $\mathrm{AO} 7$ as a model pollutant at $\mathrm{pH} 2,3,5.83$ and 7.1. Firstly, the CoFe-LDH/CF showed extremely poor removal of $\mathrm{AO} 7$ by adsorption (0 $\mathrm{mA}$ ) with less than $2 \%$ TOC and color removal (Figure 6a). As shown in Figure 6a, high level of mineralization of AO7 was achieved in a wide $\mathrm{pH}$ range from 2 to 7.1 in heterogeneous $\mathrm{EF}$ oxidation with CoFe-LDH/CF cathode at $40 \mathrm{~mA}$ applied current. For instance, TOC removal of $90,97,80$, and $66 \%$ were obtained at $\mathrm{pH} \mathrm{2,} \mathrm{3,} 5.83$ and 7.1 respectively, after $8 \mathrm{~h}$ of electrolysis. Based on literature $[12,14]$, the heterogeneous EF reaction occurs on the surface of the CoFe LDH catalyst, thus expanding the working $\mathrm{pH}$ range of the $\mathrm{EF}$ process without the precipitation of the $\mathrm{Fe} / \mathrm{Co}$ sludge. It is important to note that at lower $\mathrm{pH}$ (i.e. $\mathrm{pH} 2$ and 3) the overall mineralization of the $\mathrm{AO} 7$ is a combination of both heterogeneous oxidation at the surface of the cathode and homogeneous oxidation in the bulk solution due to the leaching of the Fe $\mathrm{Fe}^{\text {III }} \mathrm{Co}$ " from the brucite sheet of the LDH as shown by CV (Figure 5a). The ICP analysis of the treated solutions (Table 1 ) after $8 \mathrm{~h}$ shows significant leaching of the Fe"ll/Co"l in the $\mathrm{LDH}$ at $\mathrm{pH} 2$ and 3 (Table 1), confirmed the participation of the homogeneous $E F$ in the mineralization of the AO7. The CoFe-LDH catalyst was highly stable as the $\mathrm{pH}$ increases toward basic region as shown by $\mathrm{CV}$ results (Figure 5a), where the mineralization was major by heterogeneous EF reaction at the surface of the catalyst. This is apparent from the amount of $\mathrm{Fe}$ and $\mathrm{Co}$ found in the final solution, which is less than $0.08 \mathrm{mg} \mathrm{L}^{-1}$ at $\mathrm{pH} 5.83$ and 7.1 during the whole EF process (Table 1). The higher performance observed at $\mathrm{pH} 3$ compared to $\mathrm{pH} 2$ was primarily due (i) the preferential formation of peroxonium ions $\left(\mathrm{H}_{3} \mathrm{O}_{2}{ }^{+}\right)$which makes the electrogenerated $\mathrm{H}_{2} \mathrm{O}_{2}$ electrophilic and reduces its reactivity towards $\mathrm{Fe}^{2+} / \equiv \mathrm{Fe}^{\prime \prime} / \mathrm{Co} "-\mathrm{OH}$ at such low $\mathrm{pH}[11,55]$, and (ii) the transformation of ${ }^{\circ} \mathrm{OH}$ into $\mathrm{HO}_{2}$ radicals (eq. 9) which decreased the Fenton process efficiency [11, 56]. This implies that $\mathrm{H}_{2} \mathrm{O}_{2}$ was the limiting reagent at $\mathrm{pH}<2.5$. Inactivation of surfaced catalyzed process at $\mathrm{pH} 2$ due to high leaching of Co and Fe may contribute to the lower efficiency obtained at this $\mathrm{pH}$, but it is expected to be compensated by homogeneous counterpart promoted by leached $\mathrm{Co}$ and $\mathrm{Fe}$.

$\mathrm{H}_{2} \mathrm{O}_{2}+\cdot \mathrm{OH} \rightarrow \mathrm{HO}_{2} \cdot+\mathrm{H}_{2} \mathrm{O}$

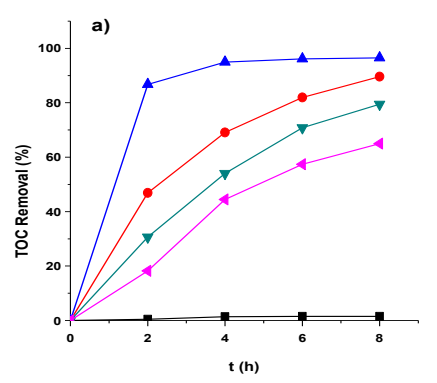

b)

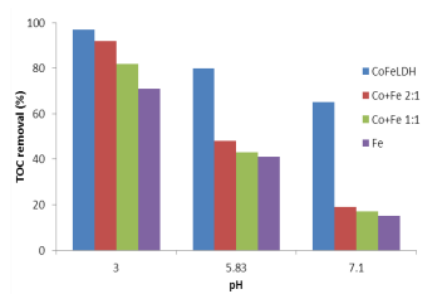

Figure 6. (a) Effect of initial solution $\mathrm{pH}$ on the mineralization of $\mathrm{AO}$ using $\mathrm{COFe}-\mathrm{LDH} / \mathrm{CF}$ synthesized at $90^{\circ} \mathrm{C}$, for $7 \mathrm{~h}$ and 25:12.5 molar concentration, (- $0 \mathrm{~mA}(\bullet) \mathrm{pH} 2,(\mathbf{\Delta}) \mathrm{pH}$ $3,(\boldsymbol{\nabla}) \mathrm{pH}$ 5.83, and ( $\mathbf{4}) \mathrm{pH} 7.1$, (b) Comparison between heterogeneous EF with CoFe$\mathrm{LDH} / \mathrm{CF}$ cathode and homogeneous $\mathrm{EF}$ with raw $\mathrm{CF}$ cathode and $\mathrm{Fe}^{2+} / \mathrm{Co}^{2+}$ at different pH. (RSD: 2\%).
Comparison studies with traditional homogeneous $\mathrm{EF}$ process using $0.2 \mathrm{mM} \mathrm{Fe}^{2+}, \mathrm{Co}^{2+}$ or $\mathrm{Fe}^{2+} / \mathrm{Co}^{2+}(1: 1$ or $1: 2 \mathrm{n} / \mathrm{n})$ and raw $\mathrm{CF}$ cathode, showed inferior mineralization compared to heterogeneous EF with CoFe-LDH at all pH studied. There was drastic reduction in mineralization efficiency in homogeneous $\mathrm{EF}$ system as the $\mathrm{pH}$ increases (Figure 6b). After $8 \mathrm{~h}$, TOC removal of $80 \%$ was attained at $\mathrm{pH} 5.83$ in heterogeneous catalysis with CoFe-LDH/CF cathode, which is at least 1.7 times that of homogeneous system with $\mathrm{Fe}^{2+} / \mathrm{Co}^{2+}$ at the same $\mathrm{pH}$. Further increase in $\mathrm{pH}$ to 7.1 causes more drastic reduction in efficiency of homogeneous system with the TOC removal less than one-third of that of heterogeneous system with CoFe$\mathrm{LDH} / \mathrm{CF}$ cathode (Figure $6 \mathrm{~b}$ ). This reduction was mainly due to $\mathrm{Fe}^{3+/} \mathrm{Co}^{3+}$ precipitation which reduce the Fenton's reaction rate. The corresponding $\mathrm{AO} 7$ conversion/degradation at $\mathrm{pH} 3$ for the comparison studies showed in Figure $5 \mathrm{~b}$ is given in Figure 7. Slightly faster degradation of AO7 was observed for homogeneous compared to heterogeneous EF process at the early stage of treatment as expected because the latter was much diffusion dependent compared to the former due to prevailing surfaced-catalyzed process that controlled the oxidation

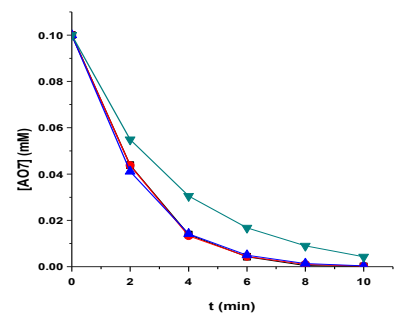

Figure 7. Degradation of $\mathrm{AO} 7$ at $\mathrm{pH} 3(\boldsymbol{\bullet}) \mathrm{Fe}^{2+},(\bullet) \mathrm{Co}+\mathrm{Fe}(1: 1),(\boldsymbol{\Delta}) \mathrm{Co}+\mathrm{Fe}(2: 1)$ ( $\mathbf{\nabla}$ ) CoFe-LDH/CF

Table 1. Concentration of $\mathrm{Co}$ and $\mathrm{Fe}$ after $8 \mathrm{~h}$ during $\mathrm{EF}$ treatment at different $\mathrm{pHs}$

\begin{tabular}{ccc}
\hline $\mathrm{pH}$ & $\mathrm{Co}\left(\mathrm{mg} \mathrm{t}^{-1}\right) \mathrm{RSD}=\mathbf{1} \%$ & $\mathrm{Fe}\left(\mathrm{mg} \mathrm{t}^{-1}\right) \mathrm{RSD}=\mathbf{1 \%}$ \\
\hline $\mathbf{2}$ & 13.69 & 4.58 \\
$\mathbf{3}$ & 2.02 & 0.63 \\
$\mathbf{5 . 8 3}$ & 0.075 & 0.061 \\
$\mathbf{7 . 1}$ & 0.041 & 0.009 \\
\hline
\end{tabular}

The mineralization of $\mathrm{AO} 7$ by ${ }^{\bullet} \mathrm{OH}$ generated by catalytic activity of CoFe-LDH/CF cathode proceeds via the formation of several aromatic/cyclic intermediates such as 4-aminophenol, hydroquinone, 1,4- benzoquinone, 1,2-naphthaquinone, 4aminobenzosulphonic acid, 4-hydroxylbenzosulphonic acid, 2hydroxy-1,4-naphthalenedione and its derivatives, 2-formyl benzoic acid, and salycilic acid which have also been reported by previous studies [57,58]. Further oxidation of these intermediates by $\cdot \mathrm{OH}$ leads to cleavage of their cyclic rings to form several short-chain carboxylic acids which were later oxidized to $\mathrm{CO}_{2}$ and $\mathrm{H}_{2} \mathrm{O}_{2}$. The reaction sequence for complete mineralization of $\mathrm{AO} 7$ by ${ }^{\circ} \mathrm{OH}$ is provided in SI Figure 1. 
The efficiency of the as-prepared CoFe-LDH/CF cathode was compared with some recent heterogeneous catalysts or electrodes reported in literature and the summary is presented in Table 2. As shown in Table 2, a very high mineralization efficiency ( $87 \%$ TOC removal after $2 \mathrm{~h}$ ) was attained with CoFeLDH/CF compared to previous studies, even though low current density of $4.2 \mathrm{~mA} \mathrm{~cm}^{-2}$ was utilized with an "active anode" of $\mathrm{Pt}$, on which there is limited mineralization of organics. Other studies $[25,27,28]$ that have reported excellent mineralization of pollutants either: (i) utilized boron-doped diamond anode (BDD) which contributes tremendously to the TOC removal due to the generation of addition hydroxyl radical $\left(\operatorname{BDD}\left({ }^{\circ} \mathrm{OH}\right)\right)$ at its surface (BDD is highly expensive) or (ii) performed the experiment at high current density $[25,28]$. Indeed, studies have shown that the $\operatorname{BDD}\left({ }^{\circ} \mathrm{OH}\right)$ induced by the boron-doped diamond anode is more efficient in mineralization of refractory carboxylic acids than the Fenton's generated ${ }^{\circ} \mathrm{OH}$ at the cathode $[1,9,10]$. Thus the excellent mineralization obtained in those previous studies was majorly due to the contribution of $\operatorname{BDD}\left(\bullet^{\circ} \mathrm{OH}\right)$ produced from water oxidation at the surface of the anode.

Table 2. Summary of some recent studies on heterogeneous EF process

\begin{tabular}{|c|c|c|}
\hline $\begin{array}{l}\text { Catalyst/ } \\
\text { electrode }\end{array}$ & $\begin{array}{l}\text { Experimental } \\
\text { conditions }\end{array}$ & $\begin{array}{l}\text { Summary/comment of the } \\
\text { efficiency }\end{array}$ \\
\hline $\begin{array}{l}\text { CoFe- } \\
\text { LDH/CF }\end{array}$ & $\begin{array}{c}40 \mathrm{mg} \mathrm{L}^{-1} \text { of } \mathrm{AO} 7 \text { at } \mathrm{pH} \\
3 \text { using Pt mesh at } 4.2 \\
\mathrm{~mA} \mathrm{~cm}\end{array}$ & $\begin{array}{l}\text { 87\% TOC removal after } 2 \mathrm{~h} ; \\
\text { and } 97 \% \text { after } 8 \mathrm{~h} \text { [present } \\
\text { study]. }\end{array}$ \\
\hline $\begin{array}{l}\mathrm{Fe}_{3} \mathrm{O}_{4} \mathrm{C}- \\
\text { aerogel }\end{array}$ & $\begin{array}{c}50 \mathrm{mg} \mathrm{L}^{-1} \text { of dimethyl } \\
\text { phthalate (DMP) at } \mathrm{pH} \\
3 \text { using BDD anode at } \\
50 \mathrm{~mA} \mathrm{~cm}^{-2}\end{array}$ & $\begin{array}{l}65 \% \text { TOC removal after } 2 \mathrm{~h} \\
\text { with major contribution of } \\
\text { oxidation at the surface of } \\
\mathrm{BDD} \text { anode }\left(\mathrm{BDD}\left({ }^{\circ} \mathrm{OH}\right)\right)[28] .\end{array}$ \\
\hline $\begin{array}{c}\text { Fe- } \\
\text { bentonite }\end{array}$ & $\begin{array}{c}100 \mathrm{mg} \mathrm{L}^{-1} \text { of orange II } \\
\text { at } \mathrm{pH} 3 \text { using graphite } \\
\text { anode at } 14.29 \mathrm{~mA} \mathrm{~cm}^{-} \\
2\end{array}$ & $\begin{array}{c}\text { 71.57\% COD removal after } 1 \\
\text { h [59] }\end{array}$ \\
\hline $\begin{array}{c}\mathrm{FeOOH} / v^{-} \\
\mathrm{Al}_{2} \mathrm{O}_{3}\end{array}$ & $\begin{array}{c}10 \mathrm{mg} \mathrm{L}^{-1} \text { rhodamine } \mathrm{B} \\
(\mathrm{RhB}) \text { at } \mathrm{pH} 3 \text { using } \\
\text { divided cell with } \mathrm{Pt} \\
\text { anode constant voltage } \\
\mathrm{E}=-0.5 \mathrm{~V}\end{array}$ & $\begin{array}{l}78.82 \% \text { TOC removal after } 2.5 \\
\text { h, with contribution of both } \\
\text { adsorption and oxidation [20] }\end{array}$ \\
\hline $\begin{array}{l}\text { Fe- } \\
\text { activated } \\
\text { carbon }\end{array}$ & $\begin{array}{l}100 \mathrm{mg} \mathrm{L}^{-1} \text { of } m \text {-cresol } \\
\text { at pH } 2 \text { using BDD } \\
\text { anode at constant } \\
\text { voltage of } 5 \mathrm{~V}\end{array}$ & $\begin{array}{l}\text { 83\% TOC removal after } 2 \mathrm{~h}, \\
\text { however with high } \\
\left.\text { contribution from BDD( }{ }^{\circ} \mathrm{OH}\right) \\
{[25] .}\end{array}$ \\
\hline Fe-alginate & $\begin{array}{c}20 \mathrm{mg} \mathrm{L}^{-1} \text { indole at } \mathrm{pH} 3 \\
\text { using } \mathrm{Pt} \text { anode at } 0.53 \\
\mathrm{~mA} \mathrm{~cm}^{-2}\end{array}$ & $\begin{array}{l}90 \% \text { TOC removal after } 7 \mathrm{~h} \\
{[21]}\end{array}$ \\
\hline $\begin{array}{c}\text { PTFE - } \\
\text { modified } \\
\text { Fe-carbon }\end{array}$ & $\begin{array}{c}120 \mathrm{mg} \mathrm{L}^{-1} 2,4- \\
\text { dichlorophenol at } \mathrm{pH} \\
6.7 \text { using DSA anode at } \\
12.5 \mathrm{~mA} \mathrm{~cm}^{-2}\end{array}$ & $\begin{array}{c}70 \% \text { TOC removal after } 6 \mathrm{~h} \\
\text { [22]. }\end{array}$ \\
\hline $\begin{array}{l}\text { Fe-CuC } \\
\text { aerogel }\end{array}$ & $\begin{array}{l}50 \mathrm{mg} \mathrm{L}^{-1} \text { methylene } \\
\text { blue at } \mathrm{pH} 3 \text { using BDD } \\
\text { anode at } 5 \mathrm{~mA} \mathrm{~cm}-2\end{array}$ & $\begin{array}{l}82 \% \text { TOC removal after } 1 \mathrm{~h} \\
\text { with } 27 \% \text { from the oxidation } \\
\text { at BBD surface }\left(\mathrm{BDD}\left(\bullet^{\circ} \mathrm{OH}\right)\right.\end{array}$ \\
\hline
\end{tabular}

[27]
$58 \mathrm{mg} \mathrm{L}^{-1}$

$\mathrm{FeS}_{2}$ using Pt anode at 100 $\mathrm{mA}$ applied current sulfamethazine at $\mathrm{pH} 3$
$69 \%$ TOC removal after $8 \mathrm{~h}$ [60]

\section{Effect of hydrothermal treatment parameters on} mineralization of $\mathrm{AO7}$

The influence of hydrothermal treatment parameters such as temperature, time and initial concentration on the mineralization of $\mathrm{AO} 7$ solution was investigated and the results were presented in Figure 8. Overall, the hydrothermal treatment parameters control the loading and the morphology of the CoFe-LDH wall on the CF substrate which in turn affects the mineralization of $\mathrm{AO} 7$ because of difference in quantity of catalyst loaded on the CF. Among studied parameters, hydrothermal treatment temperature has the greatest effect on the mineralization of AO7 (Figure 8a) with the highest TOC removal obtained with CoFe-LDH/CF synthesized at $90^{\circ} \mathrm{C}$. It is important to state that the effect of hydrothermal treatment temperature was investigated at initial molar concentration of 25:12.5 $\left(\mathrm{Co}^{2+}: \mathrm{Fe}^{3+}\right)$ and treatment time of $7 \mathrm{~h}$. The CoFe-LDH/CF synthesized at $70{ }^{\circ} \mathrm{C}$ has lower loading of CoFe-LDH compared to those synthesized at 90 or $120{ }^{\circ} \mathrm{C}$. In fact, the loading of CoFe-LDH was found to be $0.540( \pm 0.002), 7.2( \pm 0.3)$ and $7.0( \pm$ $0.3) \mathrm{mg} \mathrm{cm}-2$ for synthesis made at 70,90 and $120{ }^{\circ} \mathrm{C}$, respectively. At $70{ }^{\circ} \mathrm{C}$, the decomposition of urea and $\mathrm{NH}_{4} \mathrm{~F}$ into aqueous $\mathrm{NH}_{3}$, which initiated the concurrent precipitation of Co"/Fe"ll hydroxides into LDH, was relatively low. As such, very scanty nuclei of CoFe-LDH were formed on the CF substrate with limited growth (Figure 1b). Optimum loading obtained at $90{ }^{\circ} \mathrm{C}$ could be attributed to excellent decomposition of both urea and $\mathrm{NH}_{4} \mathrm{~F}$ at this temperature which ensured high alkalinity of the growth solution, and in turn efficient nucleation and growth of CoFe-LDH on the CF substrate as shown in Figure $1 \mathrm{c}, \mathrm{d}$. Although high loading was expected at $120^{\circ} \mathrm{C}$, but the latter was slightly lower compared to the one obtained at $90^{\circ} \mathrm{C}$. This could be explained by excessive growth of the LDH particles into heavy conglomerates which stripped them off from the substrate surface. After $8 \mathrm{~h}$ of electrolysis, the TOC removal was 73,97 and $94 \%$ for 70,90 and $120^{\circ} \mathrm{C}$, respectively. Similar effect was observed with hydrothermal treatment time and initial concentration with optimum loading of CoFe-LDH on $\mathrm{CF}$ at $7 \mathrm{~h}$ and initial molar ratio of 25:12.5 ( $\left.\mathrm{Co}^{2+}: \mathrm{Fe}^{3+}\right)$. Synthesis made at lower and longer treatment time than $7 \mathrm{~h}$ or initial molar ration other than 25:12.5 $\left(\mathrm{Co}^{2+}: \mathrm{Fe}^{3+}\right)$ shows less loading, which in turn reduced the efficiency of the heterogeneous EF system

\section{Catalyst leaching and reusability of the CoFe-LDH/CF}

The leaching of Coll and Felll from CoFe-LDH/CF cathode investigated by studying $\mathrm{EF}$ treatment of $\mathrm{AO} 7$ at $\mathrm{pH} 3$ was shown in Figure 9a. Catalytic activity and stability are important features of a good catalyst, which determine its reusability for several cycles [54]. As a heterogeneous catalyst, metal species 
leaching from solid to the bulk solution was one key issue, and must be minimized to limit the contribution of homogeneous EF and enhance the reusability of the electrode. The concentrations of both Co and Fe gradually accumulated in the treated solution with electrolysis time and 0.63 and $2.02 \mathrm{mg} \mathrm{t}^{-1}$ of Fe and Co, respectively, were found in the final solution after $8 \mathrm{~h}$ of electrolysis (Figure 9a). This implies that the mineralization of the $\mathrm{AO} 7$ was mostly due to surface-catalyzed process, even at $\mathrm{pH} 3$. The evidence of leaching at this $\mathrm{pH}$ is obvious in the SEM image and XPS analysis of the used CoFe$\mathrm{LDH} / \mathrm{CF}$ after $8 \mathrm{~h}$ of electrolysis which indicates significant removal of the needlelike structure of the LDH and reduction in XPS spectral of both Co and Fe respectively (SI Figure 2a-c). The stability of the catalytic activity of the prepared CoFe-LDH/CF was even much better at circumneutral $\mathrm{pH}$ as the leaching of metal ions from the LDH was less than $0.08 \mathrm{mg} \mathrm{t}^{-1}$ during the whole EF process as shown in Table 1.
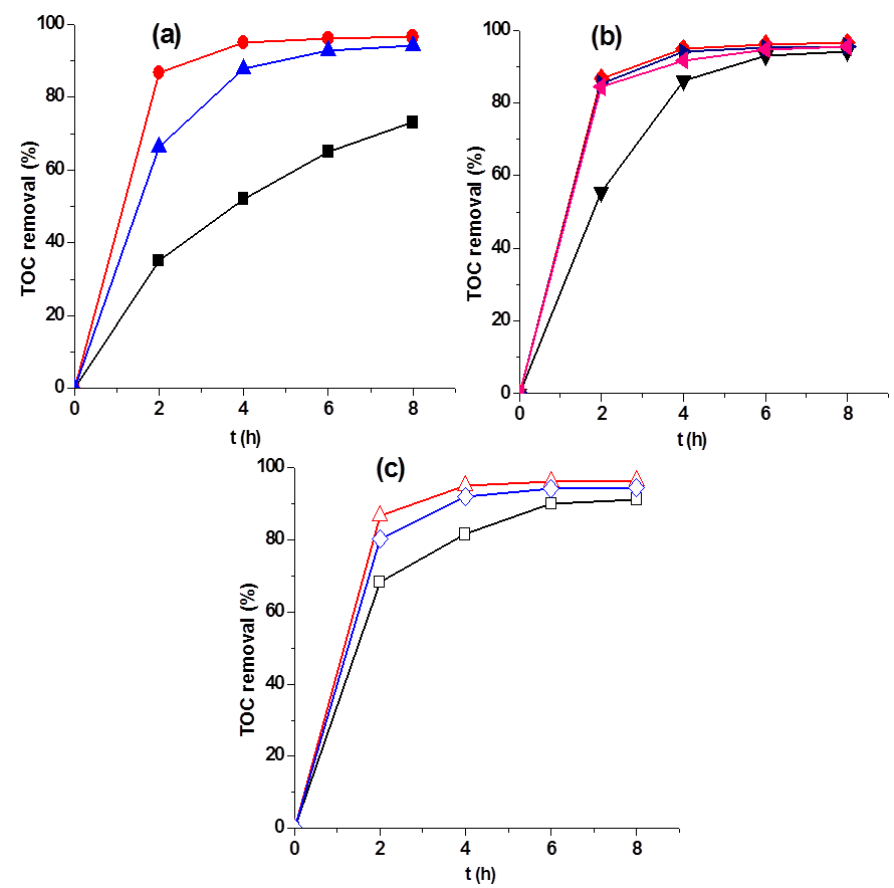

Figure 8. Effect of hydrothermal treatment parameters on the mineralization of $\mathrm{AO}$ at $\mathrm{pH}$ 3: (a) temperature $(\boldsymbol{\bullet}) 70^{\circ} \mathrm{C},(\bullet) 90^{\circ} \mathrm{C}$ and $(\boldsymbol{\Delta}) 120^{\circ} \mathrm{C}$; (b) time $(\boldsymbol{\nabla}) 4 \mathrm{~h},(\bullet) 7 \mathrm{~h},(\varangle)$ $14 \mathrm{~h}$ and $(\triangleright) 21 \mathrm{~h}$; and $(\mathrm{c})$ initial molar concentration of growth solution $\left(\mathrm{Co}^{2+}: \mathrm{Fe}^{3+}\right)(\square)$

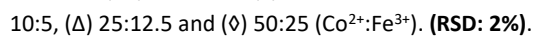

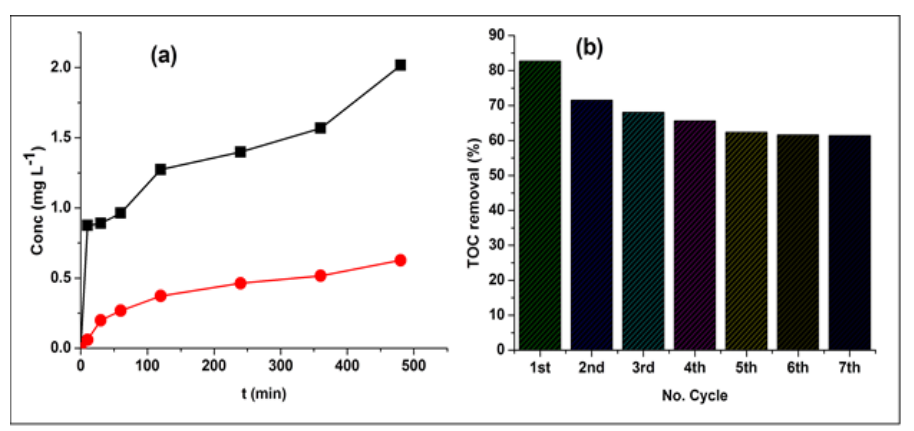

Figure 9. a) Evolution of the concentration of Fenton's catalyst/co-catalyst in the treated

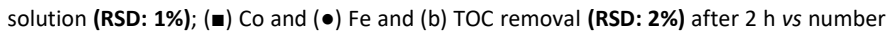
of cycles for the EF treatment using CoFe-LDH/CF synthesis at optimal conditions.

For practical environmental application and scale up, reusability of the prepared cathode was studied at $\mathrm{pH} 3$ using CoFe$\mathrm{LDH} / \mathrm{CF}\left(90{ }^{\circ} \mathrm{C} ; 7 \mathrm{~h}\right.$ and $\left.25: 12.5\right)$ dried at $80{ }^{\circ} \mathrm{C}$ after solvothermal treatment. Preliminary studies (result not reported) showed that drying as-prepared CoFe-LDH/CF at high temperature after solvothermal treatment enhanced the adhesion and stability of the catalytic activity of the CoFe-LDH on the CF substrate but with slight reduction in mineralization efficiency of AO7. Indeed $6 \%$ and $10 \%$ reduction in mineralization efficiency were observed for sample dried at 80 and $100{ }^{\circ} \mathrm{C}$ respectively. This is attributed to the gradual collapse of the porous structure of the LDH into more compacted and less porous structure which hindered the diffusion of substance towards and from the carbon-felt matrix cathode. The production of hydrogen peroxide $\left(\mathrm{H}_{2} \mathrm{O}_{2}\right)$ and reduction of leached $\mathrm{Fe}^{3+}$ to $\mathrm{Fe}^{2+}$ occur in the matrix of the carbon-felt substrate on which the LDH was deposited. As such, compacted LDH structure reduces the diffusion of substance. The reusability of CoFe-LDH/CF with number of cycles is shown in Figure 9b. After the first cycle there was sharp reduction in TOC removal (11\%) largely due to mechanical wearing of the loosely bounded CoFe-LDH on CF substrate by the highly stirred treated solution. The TOC removal was almost stable afterward up till seventh (7th) cycle with approximately $10 \%$ reduction in TOC removal (Figure 9b). Over 60\% mineralization was still feasible after $7^{\text {th }}$ cycle, indicating the good reusability of the prepared cathode.

\section{Mechanism of Efficient removal of AO7 with CoFe-LDH/CF cathode in EF oxidation}

Previous studies $[12,14]$ have shown that mechanisms of Fenton's catalytic decomposition of $\mathrm{H}_{2} \mathrm{O}_{2}$ by heterogeneous catalyst can be in two ways, depending on the working $\mathrm{pH}$. Under low acidic $\mathrm{pH}$ conditions, the process is controlled by redox cycling of $\mathrm{Fe}^{2+} / \mathrm{Fe}^{3+}$ in the solution and surface catalyzed process by $\equiv \mathrm{Fe}[\mathrm{III}]-\mathrm{OH}$ at the surface of the catalyst, with the Fe ions in the bulk comes from the dissolution of the catalyst due to acidic $\mathrm{pH}$. However at circumneutral $\mathrm{pH}$, the catalysis of the $\mathrm{H}_{2} \mathrm{O}_{2}$ should mainly occur at the catalyst surface with negligible contribution of dissolved $\mathrm{Fe}-$ species since $\mathrm{Fe}^{3+}$ is insoluble at this $\mathrm{pH}$. 


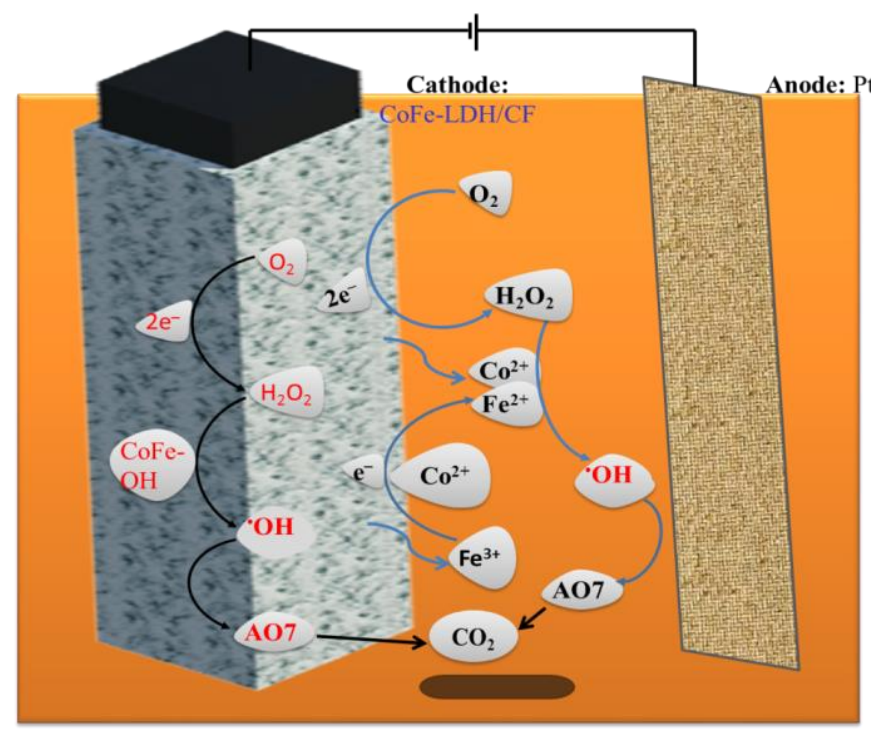

Figure 10. Schematic illustration of AO7 degradation in heterogeneous EF system with CoFe-LDH/CF cathode.

The mineralization of $\mathrm{AO} 7$ by $\mathrm{CoFe}-\mathrm{LDH} / \mathrm{CF}$ cathode was proposed based on these two mechanisms. Firstly, $\mathrm{H}_{2} \mathrm{O}_{2}$ is

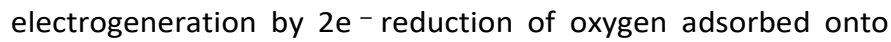
the surface of CoFe-LDH/CF cathode [1, 8-11,41,42,61], and when working at lower $\mathrm{pH} 2$ or 3 , concurrent partial leaching of Coll/Fe"ll occurs. At this $\mathrm{pH}$, both mechanism controls the oxidation of the organics. In the bulk, the leached $\mathrm{Fe}^{3+}$ is first reduced to $\mathrm{Fe}^{2+}$ by obtaining electron at the cathode, diffused into the solution and, in conjunction with $\mathrm{Co}^{2+}$ catalyzed the decomposition of $\mathrm{H}_{2} \mathrm{O}_{2}$ to produce $\cdot \mathrm{OH}$ in Fenton's (eq. 1) and Fenton-like reactions (eq. 9). The catalysis of $\mathrm{H}_{2} \mathrm{O}_{2}$ is further accelerated by regeneration of $\mathrm{Fe}^{2+}$ from reduction of $\mathrm{Fe}^{3+}$ by $\mathrm{Co}^{2+}$ (eq. 10) in the bulk, has previously reported for homogeneous EF system [36].

$\mathrm{Co}^{2+}+\mathrm{H}_{2} \mathrm{O}_{2}+\mathrm{H}^{+} \rightarrow \mathrm{Co}^{3+}+\cdot \mathrm{OH}+\mathrm{H}_{2} \mathrm{O}$

(eq. 10)

$\mathrm{Fe}^{3+}+\mathrm{Co}^{2+} \rightarrow \mathrm{Fe}^{2+}+\mathrm{Co}^{3+}$

The surface catalysis of $\mathrm{H}_{2} \mathrm{O}_{2}$, which occurs at the surface of CoFe-LDH/CF cathode and the predominant mechanism of mineralization of $\mathrm{AO} 7$ at circumneutral $\mathrm{pH}$, also started in similar manner to homogeneous system with the production of $\mathrm{H}_{2} \mathrm{O}_{2}$ in the carbon matrix of the cathode. The production of - $\mathrm{OH}$ from catalytic decomposition of $\mathrm{H}_{2} \mathrm{O}_{2}$ is strongly correlated to the production rate of $\mathrm{H}_{2} \mathrm{O}_{2}$ and the catalyst properties. The surface-catalyzed mechanism for the production of $\cdot \mathrm{OH}$ at the surface of CoFe-LDH/CF is proposed as follow:

$$
\equiv \mathrm{Fe}^{\mathrm{III}}-\mathrm{OH}+\mathrm{e}^{-} \rightarrow \equiv \mathrm{Fe}^{\mathrm{II}}-\mathrm{OH}
$$$$
\equiv \mathrm{Co}^{\mathrm{II}}-\mathrm{OH}+\equiv \mathrm{Fe}^{\mathrm{III}}-\mathrm{OH}+\rightarrow \equiv \mathrm{Co}^{\mathrm{III}}-\mathrm{OH}+\equiv \mathrm{Fe}^{\mathrm{II}}-\mathrm{OH}
$$

$\equiv \mathrm{Fe}^{\mathrm{III}} / \mathrm{Co}^{\mathrm{III}}-\mathrm{OH}+\mathrm{H}_{2} \mathrm{O}_{2} \leftrightarrow \equiv \mathrm{Fe}^{\mathrm{III}} / \mathrm{Co}^{\mathrm{III}}-\mathrm{OH}\left(\mathrm{H}_{2} \mathrm{O}_{2}\right)(\mathrm{s})$

$\equiv \mathrm{Fe}^{\mathrm{III}} / \mathrm{Co}^{\mathrm{III}}-\mathrm{OH}\left(\mathrm{H}_{2} \mathrm{O}_{2}\right)(\mathrm{s}) \rightarrow \equiv \mathrm{Fe}^{\mathrm{II}} / \mathrm{Co}^{\mathrm{II}}-\mathrm{OH}\left(\mathrm{HO}_{2}^{\circ}\right)(\mathrm{s})+$

$\mathrm{H}^{+}$

$\equiv \mathrm{Fe}^{\mathrm{II}} / \mathrm{Co}^{\mathrm{II}}-\mathrm{OH}\left(\mathrm{HO}_{2}^{\circ}\right)(\mathrm{s}) \rightarrow \equiv \mathrm{Fe}^{\mathrm{II}} / \mathrm{Co}^{\mathrm{II}}-\mathrm{OH}++\mathrm{HO}_{2}^{\cdot}+$ $\mathrm{H}^{+}$ (eq. 16)

$\mathrm{HO}_{2}^{\cdot} \leftrightarrow \mathrm{H}^{+}+\mathrm{O}_{2}^{\cdot}$ (eq. 17) $\equiv \mathrm{Fe}^{\mathrm{II}} / \mathrm{Co}^{\mathrm{II}}-\mathrm{OH}+\mathrm{H}_{2} \mathrm{O}_{2} \rightarrow \equiv \mathrm{Fe}^{\mathrm{III}} / \mathrm{Co}^{\mathrm{III}}-\mathrm{OH}+\cdot \mathrm{OH}+$ $\mathrm{OH}^{-}$

$\cdot \mathrm{OH}+\mathrm{AO} 7 \rightarrow \mathrm{CO}_{2}+\mathrm{H}_{2} \mathrm{O}$

$\cdot \mathrm{OH}+\mathrm{H}_{2} \mathrm{O}_{2} \rightarrow \mathrm{HO}_{2}^{\cdot}+\mathrm{H}_{2} \mathrm{O}$

Under circumneutral $\mathrm{pH}$ conditions $(\mathrm{pH} 5.83$ and 7.1), the application of applied current to the electrolytic cell immediately resulted in generation of large quantities of $\mathrm{H}_{2} \mathrm{O}_{2}$ (eq. 2), and $\equiv \mathrm{Fe}^{\mathrm{III}}-\mathrm{OH}$ in the $\mathrm{LDH}$ obtained an electron to partial reduced to $\equiv \mathrm{Fe}^{\mathrm{Il}}-\mathrm{OH}$ (eq. 11) $[14,20]$ or via redox reduction by $\equiv \mathrm{CO} "-\mathrm{OH}$ (eq. 12) in a similar manner obtained in homogeneous EF system. The generated $\mathrm{H}_{2} \mathrm{O}_{2}$ is adsorbed onto the surface of alkalescent $\equiv \mathrm{Fe}^{\prime \prime \prime} / \mathrm{Co}^{\prime \prime \prime \prime}$ to generate $\equiv \mathrm{Fe}^{\prime \prime \prime} / \mathrm{Co}^{\prime \prime \prime}-$ $\mathrm{OH}\left(\mathrm{H}_{2} \mathrm{O}_{2}\right)$ surface complex as presented in eq. 13, which later undergoes ground-state electron-transfer to form hydrogen peroxyl radical complex (eq. 14). The generated Fe"/ $/ \mathrm{Co}^{\prime \prime}-$ $\mathrm{OH}\left(\mathrm{HO}_{2}{ }^{\circ}\right)$ at surface of the brucite sheet of the LDH can activated itself to form $\mathrm{Fe}^{\prime \prime} / \mathrm{Co} "-\mathrm{OH}$ and $\mathrm{HO}_{2}{ }^{\circ}$ (eq. 15) with the former catalyzes the decomposition of the $\mathrm{H}_{2} \mathrm{O}_{2}$ generated on the carbon matrix to produced $\cdot \mathrm{OH}$. The $\mathrm{AO} 7$ molecules which are diffused towards and in the cathode rapidly oxidized by the generated ${ }^{\bullet} \mathrm{OH}$. Two parallel reaction pathways are possible for the produced $\cdot \mathrm{OH}$ : (i) direct oxidation of organic pollutants and (ii) destructive reaction with $\mathrm{H}_{2} \mathrm{O}_{2}$ to form $\mathrm{HO}_{2}$ (eq. 20). However, the high diffusion rate of the $\mathrm{AO} 7$ to the cathode ensure that the direct oxidation reaction is predominant and prevent the $\cdot \mathrm{OH}$ quenching, thus improving the mineralization of the pollutant. Obviously, the $\equiv \mathrm{Co} "-\mathrm{OH}$ in the LDH enhanced the production of $\cdot \mathrm{OH}$ via the Fenton-like reaction and regeneration of $\mathrm{Fe}^{\mathrm{II}}-\mathrm{OH}$ (eq. 13).

\section{Conclusions}

This study investigated a facile and simple two-steps synthesis route to produce CoFe-LDH on the surface of CF substrate for application as suitable cathode as well as heterogeneous Fenton catalyst source for electrochemical wastewater treatment over a wide range of $\mathrm{pH}$. The structure, morphology and loading of the CoFe-LDH on the CF substrate largely depended on the hydrothermal treatment temperature and time and the best synthesis was obtained at $90{ }^{\circ} \mathrm{C}$ for $7 \mathrm{~h}$ using initial $\mathrm{Co} / \mathrm{Fe}$ molar concentration ratio of 25:12.5.

The as-deposited CoFe-LDH/CF cathode exhibited high performance catalytic activity in EF treatment of AO7 over a wide $\mathrm{pH}$ range, with superior TOC removal at all $\mathrm{pH}$ studied compared to analogous homogeneous treatment with $\mathrm{Fe}^{2+}$ and/or $\mathrm{Co}^{2+}$ using raw CF cathode. The TOC removal with CoFeLDH/CF cathode was at least 1.7 and 3.5 times higher than homogeneous system with $\mathrm{Fe}^{2+} / \mathrm{Co}^{2+}$ at $\mathrm{pH} 5.83$ and 7.1 respectively.

The mineralization of $\mathrm{AO} 7$ was majorly by surfaced-catalyzed process at circumneutral $\mathrm{pH}$, whereas there is significant contribution of homogeneous EF oxidation when working at low acidic $\mathrm{pH}$ of 3 and 2. At circumneutral $\mathrm{pH}$, the catalytic activity of CoFe-LDH was very stable and the quantity of Fe and Co leached into the solution was negligible, thus minimized the anxiety of Co toxicity. Furthermore, the as-prepared CoFe- 
$\mathrm{LDH} / \mathrm{CF}$ showed relatively good reusability at $\mathrm{pH} 3$ with more that $60 \%$ TOC removal after 7 cycles of $2 \mathrm{~h}$ treatment. Based on the results obtained in this work, the CoFe-LDH/CF is a good cathode material for efficient mineralization of organic pollutants at circumneutral $\mathrm{pH}$.

\section{Acknowledgements}

The authors thank the EU for providing financial support through the Erasmus Mundus Joint Doctorate Programme ETeCoS $^{3}$ (Environmental Technologies for Contaminated Solids, Soils and Sediments, grant agreement FPA $\left.n^{\circ} 2010-0009\right)$ and the ANR (French National Research Agency) funding through ANR EcoTechnologies et EcoServices (ECO TS) - CElectrON : Couplage Electro-Oxydation et Nanofiltration pour le traitement d'effluents. The authors also wish to thank Fabienne WARMONT of Université d'Orléans for TEM analysis

\section{References}

[1] E. Brillas, I. Sires, M.A. Oturan, Electro-Fenton process and related electrochemical technologies based on Fenton's reaction chemistry, Chem. Rev. 109 (2009) 6570-6631.

[2] J.M. Peralta-Hernández, Y. Meas-Vong, F.J. Rodríguez, T.W. Chapman, M.I. Maldonado, L.A. Godínez, In situ electrochemical and photo-electrochemical generation of the fenton reagent: $A$ potentially important new water treatment technology, Water Res. 40 (2006) 1754-1762.

[3] M.A. Oturan, J. Peiroten, P. Chartrin, A.J. Acher, Complete destruction of $p$-nitrophenol in aqueous medium by electroFenton method, Environ. Sci. Technol. 34 (2000) 3474-3479.

[4] M.A. Oturan, N. Oturan, C. Lahitte, S. Trevin, Production of hydroxyl radicals by electrochemically assisted Fenton's reagent, J. Electroanal. Chem. 507 (2001) 96-102.

[5] M.A. Oturan, N. Oturan, M.C. Edelahi, F.I. Podvorica, K.E. Kacemi, Oxidative degradation of herbicide diuron in aqueous medium by Fenton's reaction based advanced oxidation processes, Chem. Eng. J. 171 (2011) 127-135.

[6] I. Sirés, F. Centellas, J.A. Garrido, R.M. Rodríguez, C. Arias, P.-L. Cabot, E. Brillas, Mineralization of clofibric acid by electrochemical advanced oxidation processes using a boron-doped diamond anode and $\mathrm{Fe}^{2+}$ and UVA light as catalysts, Appl. Catal. B Environ. 72 (2007) 373-381.

[7] A. Özcan, Y. Şahin, A.S. Koparal, M.A. Oturan, A comparative study on the efficiency of electro-Fenton process in the removal of propham from water, Appl. Catal. B Environ. 89 (2009) 620-626.

[8] M.A. Rodrigo, N. Oturan, M.A. Oturan, Electrochemically assisted remediation of pesticides in soils and water: A Review, Chem. Rev. 114 (2014) 8720-8745.

[9] H. Zhang, C. Fei, D. Zhang, F. Tang, Degradation of 4-nitrophenol in aqueous medium by electro-Fenton method, J. Hazard. Mater. 145 (2007) 227-232.

[10] C.A. Martínez-Huitle, M.A. Rodrigo, I. Sirés, O. Scialdone, Single and coupled electrochemical processes and reactors for the abatement of organic water pollutants: A critical review, Chem. Rev. 115 (2015) 13362-13407.
[11] M.A. Oturan, J.J. Aaron, Advanced oxidation processes in water/wastewater treatment: Principles and applications. A review, Crit. Rev. Environ. Sci. Technol. 44 (2014) 2577-2641.

[12] J. Li, Z. Ai, L. Zhang, Design of a neutral electro-Fenton system with $\mathrm{Fe} @ \mathrm{Fe}_{2} \mathrm{O}_{3} / \mathrm{ACF}$ composite cathode for wastewater treatment, J. Hazard. Mater. 164 (2009) 18-25.

[13] N. Qiao, H. Ma, M. Hu, Design of a neutral three-dimensional electro-Fenton system with various bentonite-based $\mathrm{Fe}$ particle electrodes: A comparative study, Mater. Res. Innov. 19 (2015) S2137-S2-141.

[14] Y. Wang, G. Zhao, S. Chai, H. Zhao, Y. Wang, Threedimensional homogeneous ferrite-carbon aerogel: One pot fabrication and enhanced electro-Fenton reactivity, ACS Appl. Mater. Interfaces 5 (2013) 842-852.

[15] A. Dirany, I. Sirés, N. Oturan, M.A. Oturan, Electrochemical abatement of the antibiotic sulfamethoxazole from water, Chemosphere 81 (2010) 594-602.

[16] I. Sirés, J.A. Garrido, R.M. Rodríguez, E. Brillas, N. Oturan, M.A. Oturan, Catalytic behavior of the $\mathrm{Fe}^{3+} / \mathrm{Fe}^{2+}$ system in the electro-Fenton degradation of the antimicrobial chlorophene, Appl. Catal. B Environ. 72 (2007) 382-394.

[17] N. Barhoumi, L. Labiadh, M.A. Oturan, N. Oturan, A. Gadri, S. Ammar, E. Brillas, Electrochemical mineralization of the antibiotic levofloxacin by electro-Fenton-pyrite process, Chemosphere 141 (2015) 250-257.

[18] L. Labiadh, M.A. Oturan, M. Panizza, N.B. Hamadi, S. Ammar, Complete removal of AHPS synthetic dye from water using new electro-fenton oxidation catalyzed by natural pyrite as heterogeneous catalyst, J. Hazard. Mater. 297 (2015) 34-41.

[19] B. Hou, H. Han, S. Jia, H. Zhuang, P. Xu, D. Wang, Heterogeneous electro-Fenton oxidation of catechol catalyzed by nano- $\mathrm{Fe}_{3} \mathrm{O}_{4}$ : kinetics with the Fermi's equation, J. Taiwan Inst. Chem. Eng. 56 (2015) 138-147.

[20] G. Zhang, Y. Zhou, F. Yang, FeOOH-Catalyzed Heterogeneous Electro-Fenton System upon Anthraquinone@Graphene Nanohybrid Cathode in a Divided Electrolytic Cell: CatholyteRegulated Catalytic Oxidation Performance and Mechanism, J. Electrochem. Soc. 162 (2015) H357-H365.

[21] S.B. Hammouda, F. Fourcade, A. Assadi, I. Soutrel, N. adhoum, A. Amrane, L. Monser, Effective heterogeneous electroFenton process for the degradation of a malodorous compound, indole, using iron loaded alginate beads as a reusable catalyst, Appl. Catal. B Environ. 182 (2016) 47-58.

[22] C. Zhang, M. Zhou, G. Ren, X. Yu, L. Ma, J. Yang, F. Yu, Heterogeneous electro-Fenton using modified iron-carbon as catalyst for 2,4-dichlorophenol degradation: Influence factors, mechanism and degradation pathway, Water Res. 70 (2015) 414424.

[23] Y. Li, A. Lu, H. Ding, X. Wang, C. Wang, C. Zeng, Y. Yan, Microbial fuel cells using natural pyrrhotite as the cathodic heterogeneous Fenton catalyst towards the degradation of biorefractory organics in landfill leachate, Electrochem. Commun. 12 (2010) 944-947.

[24] J.A. Banuelos, O. Garcia-Rodriguez, F.J. Rodriguez-Valadez, L.A. Godinez, Electrochemically prepared iron-modified activated carbon electrodes for their application in electro-Fenton and photoelectro-Fenton processes, J. Electrochem. Soc. 162 (2015) E154-E159.

[25] L. Bounab, O. Iglesias, E. González-Romero, M. Pazos, M. Ángeles Sanromán, Effective heterogeneous electro-Fenton process of $\mathrm{m}$-cresol with iron loaded actived carbon, RSC Adv. 5 (2015) 31049-31056. 
[26] S.D. Sklari, K.V. Plakas, P.N. Petsi, V.T. Zaspalis, A.J. Karabelas, Toward the development of a novel electro-Fenton system for eliminating toxic organic substances from water. Part 2. Preparation, characterization, and evaluation of iron-impregnated carbon felts as cathodic electrodes, Ind. Eng. Chem. Res. 54 (2015) 2059-2073.

[27] H. Zhao, L. Qian, X. Guan, D. Wu, G. Zhao, Continuous Bulk FeCuC aerogel with ultradispersed metal nanoparticles: An efficient 3D heterogeneous electro-Fenton cathode over a wide range of pH 3-9, Environ. Sci. Technol. 50 (2016) 5225-5233.

[28] Y. Wang, H. Zhao, G. Zhao, Highly ordered mesoporous $\mathrm{Fe}_{3} \mathrm{O}_{4} @$ Carbon embedded composite: High catalytic activity, wide $\mathrm{pH}$ range and stability for heterogeneous electro-Fenton, Electroanalysis 28 (2016) 169-176.

[29] W. Chen, X. Yang, J. Huang, Y. Zhu, Y. Zhou, Y. Yao, C. Li, Iron oxide containing graphene/carbon nanotube based carbon aerogel as an efficient E-Fenton cathode for the degradation of methyl blue, Electrochimica Acta 200 (2016) 75-83.

[30] D.G. Evans, R.C.T. Slade, Structural Aspects of Layered Double Hydroxides, in: Springer-Verlag, Berlin/Heidelberg, 2005.

[31] X. Long, Z. Wang, S. Xiao, Y. An, S. Yang, Transition metal based layered double hydroxides tailored for energy conversion and storage, Mater. Today 19 (2016) 213-226.

[32] W. He, R. Wang, L. Zhang, J. Zhu, X. Xiang, L. Feng, Enhanced photoelectrochemical water oxidation on a $\mathrm{BiVO}_{4}$ photoanode modified with multi-functional layered double hydroxide nanowalls, J. Mater. Chem. 3 (2015) 17977-17982.

[33] Y. Tang, R. Wang, Y. Yang, D. Yan, X. Xiang, Highly enhanced photoelectrochemical water oxidation efficiency based on triadic quantum dot/layered double hydroxide/BiVO 4 photoanodes, ACS Appl. Mater. Interfaces 8 (2016) 19446-19455.

[34] Q. Wang, D. O'Hare, Recent Advances in the Synthesis and Application of Layered Double Hydroxide (LDH) Nanosheets, Chem. Rev. 112 (2012) 4124-4155.

[35] L. Indira, M. Dixit, P.V. Kamath, Electrosynthesis of layered double hydroxides of nickel with trivalent cations, J. Power Sources 52 (1994) 93-97.

[36] A.M. Fogg, V.M. Green, H.G. Harvey, D. O'Hare, New separation science using shape-selective ion exchange intercalation chemistry, Adv. Mater. 11 (1999) 1466-1469.

[37] X. Duan, D.G. Evans, eds., Layered Double Hydroxides, Springer-Verlag, Berlin/Heidelberg, 2006.

[38] M. Pimentel, N. Oturan, M. Dezotti, M.A. Oturan, Phenol degradation by advanced electrochemical oxidation process electro-Fenton using a carbon felt cathode, Appl. Catal. B Environ. 83 (2008) 140-149.

[39] R. Salazar, E. Brillas, I. Sirés, Finding the best $\mathrm{Fe}^{2+} / \mathrm{Cu}^{2+}$ combination for the solar photoelectro-Fenton treatment of simulated wastewater containing the industrial textile dye Disperse Blue 3, Appl. Catal. B Environ. 115-116 (2012) 107-116.

[40] N. Oturan, M. Zhou, M.A. Oturan, Metomyl degradation by electro-Fenton and electro-Fenton-like processes: A kinetics study of the effect of the nature and concentration of some transition metal ions as catalyst, J. Phys. Chem. A 114 (2010) 10605-10611.

[41] L. Zhou, Z. Hu, C. Zhang, Z. Bi, T. Jin, M. Zhou, Electrogeneration of hydrogen peroxide for electro-Fenton system by oxygen reduction using chemically modified graphite felt cathode, Sep. Purif. Technol. 111 (2013) 131-136.

[42] T.X.H. Le, M. Bechelany, S. Lacour, N. Oturan, M.A. Oturan, M. Cretin, High removal efficiency of dye pollutants by electronFenton process using a graphene based cathode, Carbon 94 (2015) 1003-1011.
[43] W. Hajjaji, S.O. Ganiyu, D.M. Tobaldi, S. Andrejkovičová, R.C. Pullar, F. Rocha, J.A. Labrincha, Natural Portuguese clayey materials and derived $\mathrm{TiO}_{2}$-containing composites used for decolouring methylene blue (MB) and orange II (OII) solutions, Appl. Clay Sci. 83-84 (2013) 91-98.

[44] Y.M. Slokar, A. Majcen Le Marechal, Methods of decoloration of textile wastewaters, Dyes Pigments 37 (1998) 335-356.

[45] I. Sirés, E. Brillas, M.A. Oturan, M.A. Rodrigo, M. Panizza, Electrochemical advanced oxidation processes: today and tomorrow. A review, Environ. Sci. Pollut. Res. 21 (2014) 83368367.

[46] X. Cai, X. Shen, L. Ma, Z. Ji, C. Xu, A. Yuan, Solvothermal synthesis of NiCo-layered double hydroxide nanosheets decorated on RGO sheets for high performance supercapacitor, Chem. Eng. J. 268 (2015) 251-259.

[47] Y. Han, Z.-H. Liu, Z. Yang, Z. Wang, X. Tang, T. Wang, L. Fan, K. Ooi, Preparation of $\mathrm{Ni}^{2+}-\mathrm{Fe}^{3+}$ layered double hydroxide material with high crystallinity and well-defined hexagonal shapes, Chem. Mater. 20 (2008) 360-363.

[48] M. Gong, Y. Li, H. Wang, Y. Liang, J.Z. Wu, J. Zhou, J. Wang, T. Regier, F. Wei, H. Dai, An advanced Ni-Fe layered double hydroxide electrocatalyst for water oxidation, J. Am. Chem. Soc. 135 (2013) 8452-8455.

[49] Y. Li, L. Zhang, X. Xiang, D. Yan, F. Li, Engineering of ZnColayered double hydroxide nanowalls toward high-efficiency electrochemical water oxidation, J. Mater. Chem. 2 (2014) 1325013258.

[50] G. Nagaraju, G.S.R. Raju, Y.H. Ko, J.S. Yu, Hierarchical Ni-Co layered double hydroxide nanosheets entrapped on conductive textile fibers: a cost-effective and flexible electrode for highperformance pseudocapacitors, Nanoscale 8 (2016) 812-825.

[51] Y. Tang, Y. Liu, S. Yu, W. Guo, S. Mu, H. Wang, Y. Zhao, L. Hou, Y. Fan, F. Gao, Template-free hydrothermal synthesis of nickel cobalt hydroxide nanoflowers with high performance for asymmetric supercapacitor, Electrochimica Acta 161 (2015) 279289.

[52] J. Zhao, J. Chen, S. Xu, M. Shao, D. Yan, M. Wei, D.G. Evans, X. Duan, CoMn-layered double hydroxide nanowalls supported on carbon fibers for high-performance flexible energy storage devices, J. Mater. Chem. 1 (2013) 8836.

[53] T.J. Chuang, C.R. Brundle, D.W. Rice, Interpretation of the xray photoemission spectra of cobalt oxides and cobalt oxide surfaces, Surf. Sci. 59 (1976) 413-429.

[54] Q. Wang, S. Tian, J. Long, P. Ning, Use of Fe(II)Fe(III)-LDHs prepared by co-precipitation method in a heterogeneous-Fenton process for degradation of Methylene Blue, Catal. Today 224 (2014) 41-48.

[55] J. Feng, X. Hu, P.L. Yue, H.Y. Zhu, C.Q. Lu, Degradation of azodye Orange II by a photoassisted Fenton reaction, Ind. Chem. Res. 42 (2003) 2058-2066.

[56] W.Z. Tang, C.P. Huang, 2,4-dichlorophenol oxidation kinetics by Fenton's reagent, Environ. Technol. 17 (1996) 1371-1378.

[57] A. Özcan, M.A. Oturan, N. Oturan, Y. Şahin, Removal of Acid Orange 7 from water by electrochemically generated Fenton's reagent, J. Hazard. Mater. 163 (2009) 1213-1220.

[58] T.X.H. Le, T.V. Nguyen, Z.A. Yacouba, L. Zoungrana, F. Avril, E. Petit, J. Mendret, V. Bonniol, M. Bechelany, S. Lacour, G. Lesage, M. Cretin, Toxicity removal assessments related to degradation pathways of azo dyes: Toward an optimization of Electro-Fenton treatment, Chemosphere 161 (2016) 308-318. 
[59] N. Qiao, J. Chang, M. Hu, H. Ma, Novel bentonite particle electrodes based on Fenton catalyst and its application in Orange II removal, Desalination water Treat. (2015) 1-9.

[60] N. Barhoumi, N. Oturan, H. Olvera-Vargas, E. Brillas, A., Gadri, S. Ammar, M.A. Oturan, Pyrite as a sustainable catalyst in electro-Fenton process for improving oxidation of sulfamethazine. Kinetics, mechanism and toxicity assessment, Water Res. (2016) 94, 52-61.

[61] R. Wang, K. Pan, D. Han, J. Jiang, C. Xiang, Z. Huang, L. Zhang, $X$. Xiang, Solar-driven $\mathrm{H}_{2} \mathrm{O}_{2}$ generation from $\mathrm{H}_{2} \mathrm{O}$ and $\mathrm{O}_{2}$ using earth-abundant mixed-metal oxide@carbon nitride photocatalysts, ChemSusChem (2016) 9, 2470-2479.

\section{Table of content:}

LDH films are directly grown on carbon-felt to act as highperformance heterogeneous-catalyst for efficient EF mineralization of organics at near-neutral $\mathrm{pH}$

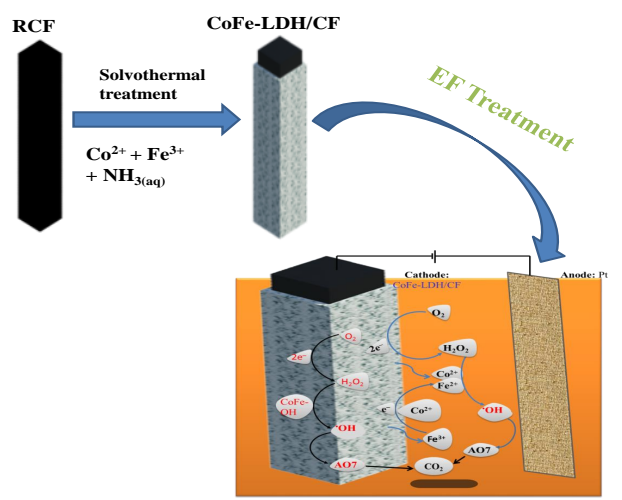

